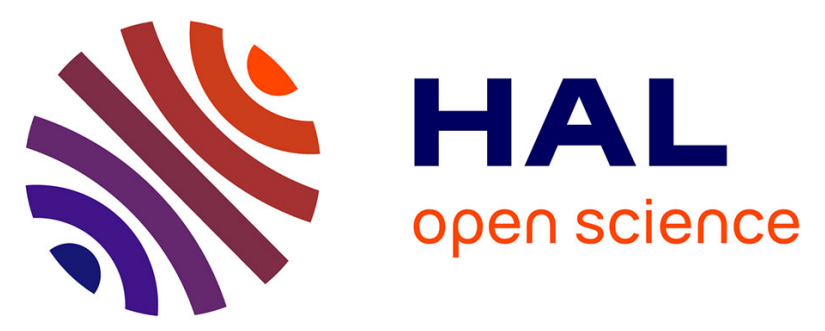

\title{
Biocide emissions from building materials during wet weather: identification of substances, mechanism of release and transfer to the aquatic environment
}

Claudia Paijens, Adèle Bressy, Bertrand Frere, Régis Moilleron

\section{To cite this version:}

Claudia Paijens, Adèle Bressy, Bertrand Frere, Régis Moilleron. Biocide emissions from building materials during wet weather: identification of substances, mechanism of release and transfer to the aquatic environment. Environmental Science and Pollution Research, In press, 10.1007/s11356-01906608-7 . hal-02324397

\section{HAL Id: hal-02324397 \\ https: / hal-enpc.archives-ouvertes.fr/hal-02324397}

Submitted on 21 Oct 2019

HAL is a multi-disciplinary open access archive for the deposit and dissemination of scientific research documents, whether they are published or not. The documents may come from teaching and research institutions in France or abroad, or from public or private research centers.
L'archive ouverte pluridisciplinaire HAL, est destinée au dépôt et à la diffusion de documents scientifiques de niveau recherche, publiés ou non, émanant des établissements d'enseignement et de recherche français ou étrangers, des laboratoires publics ou privés. 


\title{
Biocide emissions from building materials during wet weather: identification of substances, mechanism of release and transfer to the aquatic environment
}

\author{
Claudia Paijens $^{1,2}$, Adèle Bressy ${ }^{1 *}$, Bertrand Frère ${ }^{2}$ and Régis Moilleron ${ }^{3}$ \\ ${ }^{1}$ Leesu, UMR-MA-102, Ecole des Ponts ParisTech, Université Paris-Est Créteil, AgroParisTech, 6 et 8 avenue Blaise \\ Pascal - Cité Descartes, 77455 Champs-sur-Marne Cedex 2, France \\ ${ }^{2}$ Laboratoire Central de la Préfecture de Police, 39 bis rue de Dantzig, 75015 Paris, France \\ ${ }^{3}$ Leesu, UMR-MA-102, Université Paris-Est Créteil, AgroParisTech, Ecole des Ponts ParisTech, 61 avenue du \\ Général de Gaulle, 94010 Créteil Cedex, France \\ *Corresponding author: adele.bressy@enpc.fr
}

\begin{abstract}
Biocides are added to or applied on building materials to prevent microorganisms from growing on their surface or to treat them. They are leached into building runoff and contribute to diffuse contamination of receiving waters. This review aimed at summarizing the current state of knowledge concerning the impact of biocides from buildings on the aquatic environment. The objectives were (i) to assess the key parameters influencing the leaching of biocides and to quantify their emission from buildings; (ii) to determine the different pathways from urban sources into receiving waters; and (iii) to assess the associated environmental risk. Based on consumption data and leaching studies, a list of substances to monitor in receiving water was established. Literature review of their concentrations in the urban water cycle showed evidences of contamination and risk for aquatic life, which should put them into consideration for inclusion to European or international monitoring programs. However, some biocide concentration data in urban and receiving waters is still missing to fully assess their environmental risk, especially for isothiazolinones, iodopropynyl carbamate, zinc pyrithione and quaternary ammonium compounds, and little is known about their transformation products. Although some models supported by actual data were developed to extrapolate emissions on larger scales (watershed or city scales), they are not sufficient to prioritize the pathways of biocides from urban sources into receiving waters during both dry and wet weathers. Our review highlights the need to reduce emissions and limit their transfer into rivers, and reports several solutions to address these issues.
\end{abstract}

\section{KEYWORDS}

Biocides, building materials, leaching, review, risk assessment, stormwater, surface water, wastewater 


\section{Introduction}

According to the European Biocidal Product Regulation (BPR), which regulates the placing of biocidal products on the market, a biocidal product is a chemical substance or mixture that is used "with the intention of destroying, deterring, rendering harmless, preventing the action of, or otherwise exerting a controlling effect on, any harmful organism by any means other than mere physical or mechanical action" (European Parliament and Council 2012). Assessments are underway for most biocides and their uses concerning their placing on the market. Biocides are widely used in buildings to prevent microorganism growth (mosses, fungi, bacteria, algae and lichens) on their surfaces. Among the 22 types of biocidal products defined by the BPR, four are currently applied in building materials: in-can preservatives (product type 6 of the BPR), film preservatives (product type 7), wood preservatives (product type 8 ) and masonry preservatives (product type 10). They can be incorporated into the material (flat concrete roofs, renders, paints, etc.) or used for surface post-treatment (roof tiles, wooden surfaces, etc.) (Paulus 2005; Van de Voorde et al. 2012). In general, 3 to 5 biocides are applied in order to broaden the spectrum of protection. They can account for up to $0.5 \%(\mathrm{w} / \mathrm{w})$ of the total material, ranging from 300 to $4000 \mathrm{mg} / \mathrm{m}^{2}$ (Burkhardt et al. 2011). Biocides are meant to migrate from the deeper layer to the surface of the coating to act on microorganisms (Paulus, 2005) and are hence released in runoff. Similarly, biocides used for post-treatment of building materials, such as cleaning agents for roof tiles (Van de Voorde et al. 2012), are leached during wet weather and also contribute to runoff contamination. After entering the sewer network, they can be released into the aquatic environment and have negative effects on aquatic life (Singer et al. 2010; Wick et al. 2010; Wittmer et al. 2010; Moschet et al. 2015; Ccanccapa et al. 2016).

The issue of biocide emissions from buildings is of increasing concern for the aquatic environment. First, their consumption is increasing due to the growing urbanisation (Steffen et al. 2011) and the evolution of building practices such as the implementation of multilayer external thermal insulation composite system, which offers good conditions for the growth of microorganisms, or the increasing use of flat roofs (Burkhardt et al. 2012; Wicke et al. 2015). Secondly, despite their impact on ecosystems and intensive use in urban areas, biocides are still poorly regulated in the aquatic environment and thus poorly monitored (Dulio et al. 2015; Geissen et al. 2015). For example, the Water Framework Directive (European Parliament and Council 2013) covers only 4 biocides (diuron, isoproturon, terbutryn and cybutryn), which are used as plant protection products (PPPs). Finally, regulations on the discharges of wastewater or specific actions intending to reduce certain pollutants (e.g., pharmaceuticals or pesticides) proved to be effective in improving surface water quality (Botta et al. 2012; Köck-Schulmeyer et al. 2012; Palma et al. 2014; Ccanccapa et al. 2016). Similar regulations are required for biocides. So far, much attention has been paid to agricultural sources. A number of policy measures have been introduced to reduce agricultural and urban sources of pesticides, whose active substances are sometimes also used as biocides (European Parliament and Council 2009a; Barzman et al. 2015; Lamichhane et al. 2016; Lechenet et al. 2017). However, in 2015, the NORMAN network and the German Federal Environment Agency organized a workshop on environmental monitoring of biocides in Europe and pointed out the need to acquire more data on biocide 
concentrations in the aquatic environment for full risk assessment and to set up stormwater monitoring programs for source assignment (Pohl et al. 2015).

Numerous studies measured the emissions of biocides from building materials (Schoknecht et al. 2003; Jungnickel et al. 2008; Schoknecht et al. 2009; Burkhardt et al. 2011, 2012, Bollmann et al. 2016, 2017a). Many others focused on the contamination of receiving waters by biocides, which were mostly used as pesticides (Quednow and Püttmann 2007; Wick et al. 2010; Chen et al. 2012; Palma et al. 2014; Vorkamp et al. 2014; Ccanccapa et al. 2016). However, the link between the biocide emissions from buildings and their impact on receiving waters is rarely addressed (Burkhardt et al. 2011; Wicke et al. 2015). This link is difficult to establish because wet weather discharges are diffuse and biocidal substances have many other applications, especially in urban areas. Indeed, they are used as preservatives or cleaning agents (pharmaceuticals, personal care products, household products, pesticides etc.). In these cases, they unfortunately do not fall under the BPR (Wieck et al. 2016, 2018) but are covered by other regulations, such as Directive 91/414/EEC (European Parliament and Council 1991) for plant protection products or Regulation 1223/2009/EC for cosmetic products (European Parliament and Council 2009b). Therefore, the pathway between buildings and receiving waters is sometimes missing to assess the associated risk (Singer et al. 2010; Wick et al. 2010; Wittmer et al. 2010; Moschet et al. 2015; Ccanccapa et al. 2016).

In this context, the aims of this review were (i) to summarize the current state of knowledge concerning the leaching phenomenon and the urban water contamination by biocides used in buildings; (ii) to identify knowledge gaps and subsequent scientific research needed to address them, and (iii) to report policy and technical solutions in order to improve surface water quality. Therefore, four objectives were set to explore the fate of biocides used in building materials. The first one was to pinpoint the main biocides based on consumption data and leaching studies. Indeed, these substances could be transferred to runoff and thus contribute to the contamination of receiving waters via urban discharges during wet weather. The second one was to assess the key parameters influencing the leaching of biocides and their emission from paints, renders, roof sealants and treated tiles. The purpose was to generalize these emissions on a large scale (i.e., the watershed or city scales) and to provide technical options to prevent them from occurring. Mass balance between initial, remaining and released biocides was then addressed and the transformation processes that occurred in building materials were discussed. The third objective was to determine the urban sources of biocides and their different pathways to receiving waters during both dry and wet weathers. Data for biocides and their transformation products at different levels of urban water cycle (runoff, stormwater, combined sewer overflows, wastewater influents and effluents, rivers, and groundwater) were reviewed and compared to identify the main pathways, in order to help guiding actions of reduction after emissions. The final objective was to assess the environmental risk associated to the presence of biocides in receiving waters. Available data in receiving waters were compared to threshold values from regulation or ecotoxicological data. The comparison between the targeted biocides in this review and those actually monitored in the environment points out the missing data, which are required to assess global risk of biocides released from building materials, and policies that should be implemented in order to guide management and reduction of biocide uses, and thus achieving a better control of surface water quality. 


\section{Identification of the most used biocides in building materials}

Many organic biocides are used in building materials or in post-treatment products. This section identifies biocides commonly used for these purposes. Three main sources related to buildings were singled out: roofs, wood materials and façades coated with renders and paints.

\subsection{Roof treatments}

The control of microorganisms or roots may take place at different parts of the roof. Biocidal substances can be used in deslagging or de-mossing products as a post-treatment for tiles. They can be used in roof paints or in bitumen roofing membranes for flat roofs.

\subsubsection{Post-treatment of tiles}

Biocidal products can be applied on roofs to fight stains, mold and algae, and to prevent lichen proliferation. Commercial formulations contain different active substances as quaternary ammonium compounds (QAC), isothiazolinones (dichlo-octylisothiazolinone and octylisothiazolinone) and terbutryn (Van de Voorde 2012; Gromaire et al. 2015; Pena-Poza 2018). According to Van de Voorde (2012), most of the de-mossing formulations for roofs available on the French market contain quaternary ammonium compounds, in particular benzalkonium (alkyldimethylbenzylammonium). Their manufacturing process leads to a mixture of homologues with different alkyl chain lengths (from 8 to 18 carbons) and benzalkoniums mainly with 12, 14 and 16 carbons (Ferrer and Furlong 2001; INRS 2005).

\subsubsection{Roof paints}

Biocidal substances are used in organic roof paints. The use of zinc pyrithione and terbutryn was reported by Jungnickel et al. (2008) and Van de Voorde (2012). Some other compounds such as isothiazolinones (OIT), phenylureas (diuron), carbamates (carbendazim, 3-iodo-2propynylbutylcarbamate (IPBC)) or triazoles (propiconazole) were also mentioned (Jungnickel et al., 2008).

\subsubsection{Herbicides in bitumen sheets for flat roofs}

Mecoprop is an herbicide used in agriculture and in urban areas. It is often added to bitumen membranes for flat roofs to prevent roots from growing, thus maintaining roof sealing (Bucheli et al. 1998; Burkhardt et al. 2007). Unfortunately, these membranes are often over-used even though protection against root is not necessary (Wicke et al. 2015). This compound is originally registered as a plant protection product (PPP) but is currently used 3 times more as a root protection agent than in agriculture (Burkhardt et al. 2007).

\subsection{Treatment of wooden elements}

Permethrin, tolylfluanid, dichlofluanid or quaternary ammonium compounds have been widespread used since the 1980s to protect wood materials as well as azole fungicides (Kupper et al. 2005). In order to broaden their spectrum of activity, they can be applied as a mixture with 
other organic or inorganic biocides, such as IPBC (Kukowski et al. 2016), copper or boron (TirutaBarna and Schiopu 2011; Lupsea et al. 2013). For example, tecubonazole and propiconazole are often used together because of their synergic effect. Also, copper based preservatives, such as copper azole, alkaline coper quaternary or copper pentachlorophenol are often used for wood (Janin et al. 2011; Sheng et al. 2013). In recent years, nanoparticles of silver, copper or zinc oxide were used (Kaegi et al. 2010; Kaiser et al. 2013) and more recently Pereyra et al. (2014) proposed the use of A-type zeolite containing $\mathrm{Ag}^{+} / \mathrm{Zn}^{2+}$ as an inorganic antifungal for coatings.

\subsection{Paints and renders}

In recent years, organic renders and paints have been increasingly used. Unfortunately, they are vulnerable to the growth of microorganisms on their surfaces (Shirakawa et al. 2002; Burkhardt et al. 2012). In order to protect these materials, biocides are added to coating formulations (Paulus 2005). Some studies focused on the leaching of biocides from buildings, to determine whether it contributes to water pollution in urban areas or not. Isothiazolinones (Schoknecht et al. 2003, 2009, 2013; Bester and Lamani 2010), triazines (Schoknecht et al. 2003, 2009, 2013; Jungnickel et al. 2008; Bester and Lamani 2010; Burkhardt et al. 2011, 2012; Wangler et al. 2012; Styszko et al. 2014, 2015; Bollmann et al. 2016), phenylureas (Schoknecht et al. 2003, 2009, 2013; Bester and Lamani 2010; Burkhardt et al. 2011, 2012; Wangler et al. 2012; Styszko et al. 2014, 2015), carbamates (Schoknecht et al. 2003, 2009, 2013; Jungnickel et al. 2008; Bester and Lamani 2010; Burkhardt et al. 2011, 2012, Styszko et al. 2014, 2015) and triazoles (Styszko et al. 2014, 2015) appear to be the most commonly used-substances in building materials.

\subsection{Most used organic biocidal substances in building materials}

The literature review described above highlights 20 organic biocidal substances of concern which are among the most used or applied in building materials. The present review focuses on the following biocidal substances: isothiazolinones (methylisothiazolinone (MIT), benzisothiazolinone (BIT), chloro-methylisothiazolinone (CMIT), octylisothiazolinone (OIT), dichloro-octylisothiazolinone (DCOIT)), phenylureas (diuron, isoproturon), carbamates (carbendazim, iodopropynyl carbamate (IPBC)), triazines (terbutryn, cybutryn, terbuthylazine), mecoprop, azoles (propiconazole, tebuconazole, thiabendazole), permethrin, quaternary ammonium compounds (benzalkonium, dodecyl-dimethyl ammonium (DDAC)), zinc pyrithione.

\section{Leaching of biocides from building materials}

This section reviews the data concerning the quantity of biocides emitted from buildings and the parameters influencing the leaching. Most of the studies on leaching processes focused on paints and renders (Schoknecht et al. 2009; Burkhardt et al. 2011; Wangler et al. 2012; Styszko et al. 2015; Bollmann et al. 2015a; Erich and Baukh 2016; Urbanczyk et al. 2019a). Emissions from roof maintenance practices are far less documented (Van de Voorde et al. 2012; Gromaire et al. 2015). 


\subsection{Key parameters influencing leaching behaviour}

According to Uhlig et al. (2019) the leaching of biocides follows 5 steps: (i) transport of the absorbed water within the coating, (ii) desorption of the biocide from the material and dissolution in water, (iii) transport of the biocide through the material, (iv) degradation of the biocide via photolysis and hydrolysis and ( $v$ ) transfer of the biocide to water on the material surface. At the render-water interface, a partitioning equilibrium is established between the material and the water. Biocides are washed off by runoff and the remaining part migrates from the deeper layers of the material to the surface in order to restore this equilibrium (Styszko et al. 2015). Three mechanisms for the transport of biocides in polymeric renders have been suggested (Schoknecht et al. 2009; Wangler et al. 2012): (i) evaporative transport, (ii) transport through the polymer and (iii) diffusion through the water-filled pores, the predominant mechanism (Schoknecht et al. 2009; Wangler et al. 2012; Erich and Baukh 2016). Given the nature of the mechanisms involved, the leaching process is influenced by many factors such as temperature, time span between two rain events, UV exposure, biocide properties, render composition, weather conditions, etc. (Burkhardt et al. 2012; Wangler et al. 2012; Erich and Baukh 2016; Urbanczyk et al. 2019a).

One of the major parameters influencing leaching is the physical and chemical properties of the biocides. Among them, hydrophobicity, solubility and stability seem to be key parameters. Table 1 reports some properties of biocides of interest, highlighting two features:

- $\quad$ The structures and physico-chemical properties of biocides are very different. Log Kow (hydrophobicity) ranges from -0.83 (MIT) to 9.33 (zinc pyrithione), water solubility from under $0.005 \mathrm{mg} / \mathrm{L}$ (permethrin) up to $960,000 \mathrm{mg} / \mathrm{L}$ (MIT), log $\mathrm{K}_{\mathrm{oc}}$ (partition between the particulate and dissolved phases) from 1.08 (MIT) to 5.43 (benzalkonium) and Henry's constant $K_{H}$ (volatility) from $10^{-12}$ (carbendazim) to $10^{-7}$ atm. $\mathrm{m}^{3} \cdot \mathrm{mol}^{-1}$ (permethrin, DCOIT). Consequently, the variety of physical and chemical properties makes it complex to analyse biocides with a single analytical procedure (analytical column, extraction steps, chromatographic systems, etc.). Additionally, their persistence in water, expressed as the half-life (DT50), varies from less than a day to more than 2000 days, depending on the compound.

- It is difficult to gather information on biocides since many values can be found in the literature for a given parameter. Hence, several values are reported in table 1 for log $K_{\text {ow }}$ or DT50. 
Table 1. Physico-chemical properties and ecotoxicological data of biocides of concern

\begin{tabular}{|c|c|c|c|c|c|c|c|c|c|c|}
\hline $\begin{array}{c}\text { Biocide } \\
\mathrm{MW}(\mathrm{g} / \mathrm{mol})\end{array}$ & Structure & Log Kow & pKa & $\begin{array}{c}\text { WS } \\
(\mathrm{mg} / \mathrm{L})\end{array}$ & $\begin{array}{l}\log \\
\text { Koc }^{\mathrm{a}, \mathrm{I}}\end{array}$ & $\begin{array}{c}\mathrm{KH}\left(\mathrm{atm} \cdot \mathrm{m}^{3} .\right. \\
\left.\mathrm{mol}^{-1}\right)^{\mathrm{b}}\end{array}$ & $\begin{array}{l}\text { DT50 in } \\
\text { fresh } \\
\text { waters } \\
\text { (days) }\end{array}$ & $\begin{array}{c}\text { PNEC value } \\
\text { in fresh } \\
\text { water } \\
(\mu \mathrm{g} / \mathrm{L}) \\
\end{array}$ & $\begin{array}{c}\text { EC50 } \\
\text { daphnia } \\
\text { magna } \\
\text { (mg/L) 48h }\end{array}$ & $\begin{array}{l}\text { Bioconcentr } \\
\text { ation factor } \\
(\mathrm{BCF})^{\prime}\end{array}$ \\
\hline $\begin{array}{c}\text { Benzalkonium } \\
\text { chlorides C12- } \\
\text { C16 } \\
304.5-388.7 \\
\end{array}$ & & $1.69-3.42^{c}$ & & $100000^{d}$ & 5.43 & & $30^{e}$ & $\begin{array}{c}\mathrm{S} 12-\mathrm{S} 16- \\
0.415^{\mathrm{s}} \\
\mathrm{S} 12-0.04^{\alpha}\end{array}$ & $0.041^{\beta}$ & 10.79 \\
\hline $\begin{array}{c}\text { BIT } \\
151.2\end{array}$ & & $0.64^{f}$ & & $22204^{b}$ & 1.53 & & $>50^{g}$ & - & $0.85^{\gamma}$ & 3.16 \\
\hline $\begin{array}{c}\text { Carbendazim } \\
191.2 \\
\end{array}$ & & $1.51^{j}$ & $4.20^{\mathrm{h}}$ & $1.55^{b}$ & 2.39 & $1.5^{*} 10^{-12}$ & $42^{k}-350^{1}$ & $0.034^{v}$ & $0.087^{u}$ & 27 \\
\hline $\begin{array}{l}\text { CMIT } \\
149.6\end{array}$ & & $\begin{array}{l}-0.34^{\prime}- \\
0.4^{m}\end{array}$ & & $\begin{array}{l}\text { Highly } \\
\text { soluble }^{n}\end{array}$ & & & $3^{m}-6.6^{n}$ & $0.049^{h}$ & $0.16^{* e}$ & $<54$ \\
\hline $\begin{array}{c}\text { Cybutryn } \\
253.4\end{array}$ & & $2.58^{\mathrm{f}}-3.95^{\mathrm{I}}$ & $4.1^{j}$ & $20^{b}$ & 2.4 & $5.3^{*} 10^{-9}$ & $30^{\circ}$ & $0.001^{v}$ & $2.4^{\mathrm{h}}$ & 250 \\
\hline $\begin{array}{l}\text { DCOIT } \\
282.2\end{array}$ & & $3.59^{\mathrm{b}}-4.9^{\mathrm{m}}$ & & $27^{m}$ & 3.35 & $1.9 .10^{-7}$ & $<1^{p}$ & $0.008^{v}$ & $0.0052^{\mathrm{e}}$ & 108.6 \\
\hline $\begin{array}{c}\text { DDAC (C10) } \\
326.6\end{array}$ & & $-0.41^{q}$ & & $650^{r}$ & & & $30^{\mathrm{s}}$ & $0.38^{\mathrm{s}}$ & $0.062^{q}$ & 81 \\
\hline $\begin{array}{c}\text { Diuron } \\
233.1\end{array}$ & & $\begin{array}{l}2.71^{\mathrm{m}}- \\
2.85^{\mathrm{f}, \mathrm{j}}\end{array}$ & & $102^{b}$ & 2.59 & $5.3 * 10^{-10}$ & $\begin{array}{l}113^{\mathrm{a}}- \\
2190^{\mathrm{m}}\end{array}$ & $0.02^{v}$ & $5.7^{\mathrm{h}}$ & 2 \\
\hline $\begin{array}{l}\text { IPBC } \\
281.1 \\
\end{array}$ & & $\begin{array}{l}2.4^{m_{-}} \\
2.81^{f, j, l}\end{array}$ & & $436^{b}$ & & $6.9 * 10^{-9}$ & $7-139^{t}$ & $0.026^{v}$ & - & 19.33 \\
\hline $\begin{array}{l}\text { Isoproturon } \\
206.3\end{array}$ & & $2.50^{f, j, l}$ & & $92^{b}$ & 2.14 & $1.9 * 10^{-9}$ & $\begin{array}{l}30^{p_{-}} \\
1560^{h}\end{array}$ & $0.021^{\mathrm{u}}$ & $0.56^{\mathrm{u}}$ & 3.6 \\
\hline $\begin{array}{l}\text { Mecoprop } \\
214.6\end{array}$ & & $\begin{array}{l}-0.19^{\prime}- \\
0.1^{f, j}\end{array}$ & $3.74^{j}$ & $471^{b}$ & 1.41 & $1.8^{*} 10^{-8}$ & $31^{i}$ & $44^{u}$ & $200^{4}$ & 3.16 \\
\hline $\begin{array}{l}\text { MIT } \\
115.2\end{array}$ & & $\begin{array}{l}-0.83^{\prime}- \\
0.5^{m}\end{array}$ & & $960000^{b}$ & 1.08 & $5 * 10^{-8}$ & $\begin{array}{l}18,2^{n}- \\
30^{m}\end{array}$ & $3.9^{\text {h }}$ & $0.16^{* e}$ & 3.16 \\
\hline
\end{tabular}




\begin{tabular}{|c|c|c|c|c|c|c|c|c|c|c|}
\hline $\begin{array}{c}\text { OIT } \\
213.3\end{array}$ & $\mathrm{CH}_{3}$ & $\begin{array}{l}2.45^{\mathrm{f}, j_{-}} \\
2.61^{\mathrm{b}}\end{array}$ & & $309^{b}$ & 2.13 & $3.6 * 10^{-7}$ & $>30^{p}$ & $0.013^{v}$ & $0.32^{\mathrm{e}}$ & 19.21 \\
\hline $\begin{array}{c}\text { Permethrin } \\
391.3\end{array}$ & & $6.1^{\mathrm{u}}$ & & $<0.005^{\mathrm{u}}$ & 4.59 & $\begin{array}{c}4.6^{*} 10^{-8}-> \\
4.5^{*} 10^{-7} u\end{array}$ & $<3^{\mathrm{u}}$ & $0.00047^{u}$ & $0.00127^{\mathrm{u}}$ & $500-570^{u}$ \\
\hline $\begin{array}{c}\text { Propiconazole } \\
342.2\end{array}$ & & $3.72^{\mathrm{j}, \mathrm{I}}$ & $1.09^{h}$ & $11^{\mathrm{b}}$ & 2.82 & $14 * 10^{-9}$ & $6.4^{\mathrm{v}}-30^{\mathrm{i}}$ & $6.8^{\mathrm{u}}$ & $4.8^{\mathrm{e}}$ & 180 \\
\hline $\begin{array}{c}\text { Tebuconazole } \\
307.8\end{array}$ & & $3.5^{\mathrm{l}}-3.7^{\mathrm{j}}$ & $5.00^{h}$ & $97^{b}$ & 3 & $5.1 * 10^{-10}$ & $28^{i}$ & $1^{\mathrm{u}, \mathrm{e}}$ & $4^{e}$ & 78 \\
\hline $\begin{array}{c}\text { Terbuthylazine } \\
229.7\end{array}$ & & $3.04^{\mathrm{j}}-3.4^{\mathrm{l}}$ & $2^{j}$ & $6.6^{1}$ & 2.34 & $1.6 * 10^{-11 ~ h}$ & $77^{i}$ & $0.06^{\mathrm{u}}$ & $21.2^{h}$ & 34 \\
\hline $\begin{array}{c}\text { Terbutryn } \\
241.4\end{array}$ & & $3.65^{f, j, l}$ & $4.30^{h}$ & $42^{b}$ & 3.30 & $9.1 * 10^{-9}$ & $354^{i}$ & $0.034^{v}$ & $2.6^{\mathrm{h}}$ & 41.47 \\
\hline $\begin{array}{c}\text { Thiabendazole } \\
201.2\end{array}$ & & $2.39^{1, h, w}$ & $\begin{array}{c}4.73 \& \\
12^{h, w}\end{array}$ & $31^{w}$ & 2.40 & $1.4,10^{-11} \mathrm{w}$ & $203^{h, w}$ & $1.2^{\mathrm{W}}$ & $0.81^{\mathrm{W}}$ & $96.5^{\mathrm{W}}$ \\
\hline $\begin{array}{c}\text { Zinc pyrithione } \\
317.7\end{array}$ & & $9.33^{x}$ & & $8^{y}$ & & & $<1^{2}$ & $0.0026^{v}$ & $0.034^{e}$ & \\
\hline
\end{tabular}

\section{*Value for CMIT/MIT (3/1) mixture}

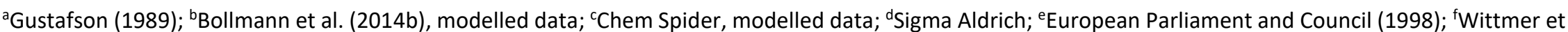
al. (2010); ${ }^{B}$ Bürgi et al. (2009); ' 'University of Hertfordshire, PPDB; 'PAN Pesticides Database; 'Wick et al. (2010); ${ }^{k}$ Cuppen et al. (2000); 'INERIS; ${ }^{\mathrm{m} P a u l u s}$ (2005);

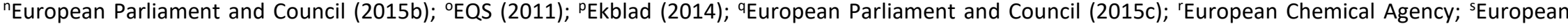
Parliament and Council (2015a); tJuergensen et al. (2000); " European Parliament and Council (2014); ${ }^{\mathrm{V} E u r o p e a n ~ P a r l i a m e n t ~ a n d ~ C o u n c i l ~(2015 d) ; ~}{ }^{2} E u r o p e a n$ Parliament and Council (2008); ${ }^{X}$ Sánchez-Bayo and Goka (2005); ${ }^{\vee}$ Burkhardt et al. (2009); ${ }^{\mathrm{Y} Y a m a d a ~(2007) ; ~}{ }^{\alpha}$ Uhl et al. (2005); ${ }^{\beta}{ }^{K}$ reuzinger et al. (2007); ${ }^{\vee}$ Nautiel, SDS. 
Schoknecht et al. (2009) and Burkhardt et al. (2012) showed that biocides from the same family can have similar leaching behaviour (as for triazines or phenylureas). This is not a generic rule, as in the case of isothiazolinones (DCOIT and OIT). Moreover, it was expected that water solubility (WS) and hydrophobicity (log $\mathrm{K}_{\mathrm{ow}}$ ) would be correlated with the calculated desorption constant $\left(K_{d}\right)$, which was not the case in practice. According to Styszko et al. (2014), $K_{o w}$ and $K_{d}$ were correlated only at neutral $\mathrm{pH}, \mathrm{pH}$ at which the $\mathrm{K}_{\mathrm{ow}}$ is often given. However, the $\mathrm{pH}$ of the waterfilled pores is basic and the $\mathrm{pH}$ of the runoff on the surface is more acidic. The same authors have shown that concentrations of biocides in runoff are considerably lower than their water solubilities. The nature of the material, such as the composition of the render (e.g. the organic fraction), led also to different emissions. Emissions of carbamates, isothiazolinones and triazines were influenced by the render composition unlike phenylureas. The silicone render led to fewer biocide emissions, probably because of a higher organic matter fraction (Styszko et al. 2014, 2015; Bollmann et al. 2016, 2017b).

Regarding environmental conditions, Jungnickel et al. (2008) highlighted the impact of rain intensity and cumulative rain duration after application of the compound, on its concentration in runoff. Significant concentrations can be observed especially after low-intensity rainfall (0.3 mm/h). According to Wangler et al. (2012) and Burkhardt et al. (2011, 2012), a rise in temperature tends to increase the release of biocides from façades, possibly due to faster diffusion. The partitioning and chemical interaction may change with temperature. At higher temperatures, chemical interactions may be reduced, leading to higher release. Also, biocides can be degraded by environmental conditions (hydrolysis, biodegradation or direct and indirect photolysis (Fenner et al. 2013)), resulting in lower emissions of the parent compounds but higher emissions of transformation products over time.

\subsection{Release of biocides from buildings during rain events}

The quantity of biocides emitted from leaching in runoff is not constant over time and, as described previously, depends on various parameters. Leaching of biocides mostly occurs within the first months after application (Bollmann et al. 2016, 2017b) and tends to decrease exponentially with time (Jungnickel et al. 2008; Wittmer et al. 2011b). In addition, this leaching is discontinuous (Bollmann et al. 2016; Schoknecht et al. 2016) and depends on rain events. Even though the main part remains in the material, biocides can still be released after numerous rain events (Burkhardt et al. 2011): Riechel et al. (2015) and Hensen et al. (2018) showed the release of compounds even after more than 15 years. It is therefore difficult to estimate the quantities of biocides emitted from buildings during rainy weather. These emissions were studied on two scales. Some lab or building-scale studies investigated the leaching behaviour in order to assess the emissions under controlled conditions. Based on these findings, release models were developed to simulate the emissions on a larger scale.

\subsubsection{Small-scale emissions}

Table 2 reports cumulative emissions found in the literature and the percentages of losses from the material compared with the initial quantity. Concerning paints and renders, the values are highly variable from one compound to another but also for a given compound. For instance, cumulative emissions ranged from 0.6 to $178 \mathrm{mg} / \mathrm{m}^{2}$ for carbendazim, from 0.5 to $1012 \mathrm{mg} / \mathrm{m}^{2}$ 
for terbutryn, from 6 to $1730 \mathrm{mg} / \mathrm{m}^{2}$ for diuron, from 2.5 to $1376 \mathrm{mg} / \mathrm{m}^{2}$ for OIT or from 56 to $5041 \mathrm{mg} / \mathrm{m}^{2}$ for BIT (biocides are listed in increasing order of water solubility). For most of the biocides, the main part remains in the material. The percentages of losses vary from 1 to $33 \%$ for carbendazim, from 1 to $34 \%$ for terbutryn, from 7 to $62 \%$ for diuron, from 2 to $29 \%$ for OIT. However, biocides just used as in-can preservatives are not expected to remain in the material in the long term. For instance, Schoknecht et al. (2009) reported leached quantities up to $100 \%$ of the initial quantity of BIT in the material. Emission differences observed between compounds are linked to their physicochemical properties. In particular, releases tend to increase with water solubility. Variability between studies is also linked to the different experimental procedures which have been performed: lab-scale or real building, exposure to water, initial quantity of substances etc. Schoknecht et al. (2009) compared emissions from three different leaching tests on the lab scale and demonstrated the importance of the contact time with water. Only a few studies investigated leaching of biocides from paints and renders under natural weather conditions. Burkhardt et al. (2012) and Bollmann et al. $(2016,2017 \mathrm{~b})$ exposed panels coated with renders and paints to natural weather during at least one year. They measured higher emissions of biocides compared to those obtained following the EN 16105 (CEN 2011) procedure used by Schoknecht et al. (2013), possibly due to a higher initial amount of biocides in the material. However, the percentages of leached biocides assessed under natural weather were slightly lower compared with those obtained in the lab-study. Consequently, considering a same initial amount of biocides, the EN 16105 procedure could overestimate both the emission rates and the associated risk assessment. 
Table 2. Cumulative emissions of biocides from leaching experiment on the lab-scale or semi-technical scale and percentages of biocides leached (DR, diuron; IP, isoprotuon; TB, terbutryn; CB, cybutryn; CBZ, carbendazim; TEB, tebuconazole; BZK, benzalkonium)

\begin{tabular}{|c|c|c|c|c|c|c|c|c|c|c|c|c|c|c|c|c|}
\hline \multirow[t]{2}{*}{ Reference } & \multirow[t]{2}{*}{ Material } & \multirow{2}{*}{$\begin{array}{l}\text { Concentration of } \\
\text { each biocide }\end{array}$} & \multirow{2}{*}{$\begin{array}{l}\text { Exposition to } \\
\text { water }\end{array}$} & \multicolumn{13}{|c|}{$\begin{array}{l}\text { Cumulative emissions in } \mathrm{mg} / \mathrm{m}^{2} \\
\text { (\% of losses) }\end{array}$} \\
\hline & & & & DR & IP & TB & CB & CBZ & IPBC & DCOIT & OIT & BIT & MIT & TEB & MCPP & BZK \\
\hline \multirow{3}{*}{$\begin{array}{l}\text { Burkhardt et al. } \\
\text { (2011) }\end{array}$} & Render & $1500 \mathrm{~g} / \mathrm{m} 2$ & Sprinkling & $\begin{array}{l}435 \\
(29) \\
\end{array}$ & & $\begin{array}{l}315 \\
(21) \\
\end{array}$ & $\begin{array}{l}285 \\
(19) \\
\end{array}$ & $\begin{array}{r}105 \\
(7) \\
\end{array}$ & & & & & & & & \\
\hline & \multirow{2}{*}{ Marketed sealants } & $\begin{array}{c}4.8 \mathrm{~g} / \mathrm{m} 2 \\
\text { (Preventolo } \\
\end{array}$ & \multirow{2}{*}{ Sprinkling } & & & & & & & & & & & & $\begin{array}{l}12.4 \\
(0.2) \\
\end{array}$ & \\
\hline & & $\begin{array}{c}3.0 \mathrm{~g} / \mathrm{m} 2 \\
\text { (Herbitect }^{\oplus} \text { ) }\end{array}$ & & & & & & & & & & & & & $\begin{array}{c}1.1 \\
(0.04) \\
\end{array}$ & \\
\hline \multirow{2}{*}{$\begin{array}{l}\text { Styszko et al. } \\
\quad(2015)\end{array}$} & Silicone render & $11.4 \mu \mathrm{g} / \mathrm{g}$ & \multirow{2}{*}{ Immersion } & $\begin{array}{r}2.9-5.0 \\
(7-12) \\
\end{array}$ & $\begin{array}{l}8.9-12.1 \\
(21-29) \\
\end{array}$ & $\begin{array}{c}0.5-2.2 \\
(1-5)\end{array}$ & $\begin{array}{l}0.5-4 \\
(1-9) \\
\end{array}$ & $\begin{array}{c}0.8-2.7 \\
(2-6)\end{array}$ & $\begin{array}{c}1.1-2.1 \\
(3-5)\end{array}$ & \begin{tabular}{|l|}
$0.02-0.24$ \\
$(0.1-0.6)$ \\
\end{tabular} & $\begin{array}{c}2.5-13.6 \\
(5-29) \\
\end{array}$ & 61.8-142 & $\begin{array}{l}106- \\
295 \\
\end{array}$ & $\begin{array}{c}0.2-1.1 \\
(1-3)\end{array}$ & & \\
\hline & Acrylate render & $11.4 \mu \mathrm{g} / \mathrm{g}$ & & $\begin{array}{l}4.8-8.0 \\
(12-19) \\
\end{array}$ & $\begin{array}{c}12.8-15.8 \\
(29-36) \\
\end{array}$ & $28-62$ & $\begin{array}{l}1.7-6.1 \\
(3-13) \\
\end{array}$ & $\begin{aligned} 7.5-34 \\
(18-77) \\
\end{aligned}$ & $\begin{array}{c}1.1-3.2 \\
(3-8)\end{array}$ & \begin{tabular}{|l|}
$0.05-0.2$ \\
$(0.1-0.5)$ \\
\end{tabular} & $60-217$ & 82.8-189 & $\begin{array}{l}211- \\
465 \\
\end{array}$ & $\begin{array}{c}1.3-3.6 \\
(3-8)\end{array}$ & & \\
\hline \multirow{3}{*}{$\begin{array}{l}\text { Schoknecht et al. } \\
\text { (2009) }\end{array}$} & \multirow{3}{*}{$\begin{array}{c}\text { Acrylate render + } \\
\text { silicon paint }\end{array}$} & \multirow{3}{*}{$\begin{array}{l}2250-3000 \\
\mathrm{mg} / \mathrm{m} 2\end{array}$} & Irrigation & $6-15$ & $8-21$ & $1-5$ & $1-4$ & $0.6-1.3$ & $3-7$ & $0.5-1$ & $9-22$ & $56-155$ & & & & \\
\hline & & & $\begin{array}{l}\text { Short-term } \\
\text { immersion }\end{array}$ & 59-180 & 114-239 & $16-53$ & $17-47$ & 73-178 & 23-82 & $5-14$ & $11-254$ & 448-836 & & & & \\
\hline & & & $\begin{array}{l}\text { Permanent } \\
\text { immersion }\end{array}$ & 399-739 & 735-1484 & $96-300$ & $97-270$ & $5-30$ & 164-332 & $18-37$ & 634-1376 & 3100-5041 & & & & \\
\hline \multirow{2}{*}{$\begin{array}{c}\text { Schoknecht et al. } \\
\text { (2013) }\end{array}$} & Render & $780 \mathrm{mg} / \mathrm{m} 2$ & \multirow{2}{*}{$\begin{array}{l}\text { Short-term } \\
\text { immersion }\end{array}$} & $\begin{array}{c}99 \\
(12.7)\end{array}$ & & $\begin{array}{c}25 \\
(3.2) \\
\end{array}$ & & $\begin{array}{c}19 \\
(2.4)\end{array}$ & $\begin{array}{c}46 \\
(5.9) \\
\end{array}$ & $\begin{array}{c}5 \\
(0.6) \\
\end{array}$ & $\begin{array}{c}97 \\
(12.4)\end{array}$ & & & & & \\
\hline & Paint & $230 \mathrm{mg} / \mathrm{m} 2$ & & $\begin{array}{c}57 \\
(24.8) \\
\end{array}$ & & $\begin{array}{c}9 \\
(3.9) \\
\end{array}$ & & $\begin{array}{c}15 \\
(6.5) \\
\end{array}$ & $\begin{array}{c}36 \\
(15.7) \\
\end{array}$ & $\begin{array}{c}4 \\
(1.7) \\
\end{array}$ & $\begin{array}{c}54 \\
(23.4) \\
\end{array}$ & & & & & \\
\hline \multirow{2}{*}{$\begin{array}{l}\text { Wangler et al. } \\
\quad \text { (2012) }\end{array}$} & Organic render & $\begin{array}{c}2100- \\
2400 \mathrm{mg} / \mathrm{m} 2\end{array}$ & \multirow{2}{*}{ Sprinkling } & $\begin{array}{c}622-1451 \\
(30-45)\end{array}$ & $\begin{array}{c}618-1534 \\
(29-64)\end{array}$ & $\begin{array}{r}324-919 \\
(14-34)\end{array}$ & $\begin{array}{l}285-727 \\
(12-30)\end{array}$ & & $\begin{array}{c}421-1234 \\
(20-51)\end{array}$ & $\begin{array}{l}94-299 \\
(4-12)\end{array}$ & $\begin{array}{c}128-502 \\
(6-21)\end{array}$ & & & & & \\
\hline & $\begin{array}{c}\begin{array}{c}\text { Render + silicone } \\
\text { paint }\end{array} \\
\end{array}$ & $\begin{array}{c}2800- \\
3000 \mathrm{mg} / \mathrm{m} 2 \\
\end{array}$ & & $\begin{array}{c}1570-1730 \\
(53-62) \\
\end{array}$ & $\begin{array}{c}1613-1841 \\
(58-60) \\
\end{array}$ & $\begin{array}{c}624-1012 \\
(22-34) \\
\end{array}$ & $\begin{array}{l}650-988 \\
(23-33) \\
\end{array}$ & & $\begin{array}{c}823-1547 \\
(29-50) \\
\end{array}$ & $\begin{array}{c}\begin{array}{c}202-595 \\
(7-19)\end{array} \\
\end{array}$ & $\begin{array}{c}296-620 \\
(10-20) \\
\end{array}$ & & & & & \\
\hline $\begin{array}{c}\text { Jungnickel et al. } \\
\text { (2008) } \\
\end{array}$ & $\begin{array}{c}4 \text { commercial roof } \\
\text { paints }\end{array}$ & & Immersion & & & $10-25$ & & $10-60$ & & & & & & & & \\
\hline \multirow{2}{*}{$\begin{array}{l}\text { Bucheli et al. } \\
\text { (1998) }\end{array}$} & $\begin{array}{l}\text { Bitumous roofing } \\
\text { membranes }\end{array}$ & & Spraying & & & & & & & & & & & & $0.026-0.26$ & \\
\hline & 3 roofs $(5100 \mathrm{~m} 2)$ & & $\begin{array}{c}\text { Natural weather } \\
\text { during } 5 \text { days }\end{array}$ & & & & & & & & & & & & 0.12 & \\
\hline $\begin{array}{l}\text { Riechel et al. } \\
\text { (2015) }\end{array}$ & $\begin{array}{l}\text { Green roof with } \\
\text { bituminous } \\
\text { membrane }\end{array}$ & & $\begin{array}{l}\text { Natural weather } \\
\text { during } 7 \text { months }\end{array}$ & & & & & & & & & & & & 0.24 & \\
\hline \multirow{2}{*}{$\begin{array}{l}\text { Bollmann et al. } \\
\text { (2016, 2017b) }\end{array}$} & Silicone render & $\begin{array}{c}1.2 \mathrm{~g} / \mathrm{kg} \text { for } \\
\text { terbutryn and } 6.2 \\
\mathrm{~g} / \mathrm{m} 2 \text { for OIT }\end{array}$ & \multirow{2}{*}{$\begin{array}{l}\text { Natural weather } \\
\text { during } 1.5 \mathrm{y}\end{array}$} & & & $\begin{array}{l}65 \\
(3) \\
\end{array}$ & & & & & $\begin{array}{l}120 \\
(2)\end{array}$ & & & & & \\
\hline & Acrylate render & $\begin{array}{c}1.7 \mathrm{~g} / \mathrm{kg} \text { for } \\
\text { terbutryn and } \\
13.6 \mathrm{~g} / \mathrm{m} 2 \text { for OIT }\end{array}$ & & & & $\begin{array}{l}150 \\
(3)\end{array}$ & & & & & $\begin{array}{l}250 \\
(2)\end{array}$ & & & & & \\
\hline \multirow{2}{*}{$\begin{array}{l}\text { Burkhardt et al. } \\
\text { (2012) }\end{array}$} & Render & $2250 \mathrm{mg} / \mathrm{m} 2$ & \multirow{2}{*}{$\begin{array}{c}\text { Natural weather } \\
\text { during } 1 \mathrm{y}\end{array}$} & $\begin{array}{l}225 \\
(9.5)\end{array}$ & 440 (18.4) & $\begin{array}{c}15 \\
(0.6)\end{array}$ & $\begin{array}{c}15 \\
(0.6)\end{array}$ & & $\begin{array}{c}84 \\
(3.5)\end{array}$ & $\begin{array}{c}1 \\
(0.05)\end{array}$ & $\begin{array}{c}48 \\
(2.0)\end{array}$ & & & & & \\
\hline & Render and paint & $3000 \mathrm{mg} / \mathrm{m} 2$ & & $\begin{array}{r}180-400 \\
(7.5-13) \\
\end{array}$ & $\begin{array}{l}499-573 \\
(16-23) \\
\end{array}$ & $\begin{array}{c}50-10 \\
(2.1-3.5) \\
\end{array}$ & $\begin{array}{c}54-122 \\
(2.3-5.1) \\
\end{array}$ & & $\begin{array}{c}147-311 \\
(6.2-10.4) \\
\end{array}$ & $\begin{array}{c}2-15 \\
(0.1-0.5) \\
\end{array}$ & $\begin{array}{c}59-116 \\
(2.5-3.9) \\
\end{array}$ & & & & & \\
\hline \multirow{2}{*}{$\begin{array}{l}\text { Gromaire et al. } \\
\text { (2015) }\end{array}$} & Old clay tiles & \multirow{2}{*}{$5900 \mathrm{mg} / \mathrm{m} 2$} & \multirow{2}{*}{$\begin{array}{l}\text { Natural weather } \\
\text { during } 13 \mathrm{~m}\end{array}$} & & & & & & & & & & & & & $\begin{array}{l}152 \\
(2)\end{array}$ \\
\hline & Concrete tiles & & & & & & & & & & & & & & & $\begin{array}{l}1683 \\
(27) \\
\end{array}$ \\
\hline
\end{tabular}


Concerning mecoprop used in roof sealant, emissions vary from 0.026 to $12.4 \mathrm{mg} / \mathrm{m}^{2}$ (Bucheli et al. 1998; Burkhardt et al. 2011; Riechel et al. 2015). Bucheli et al. (1998) compared emissions from two roofs equipped with two different bituminous roofing membranes containing the product Preventol $\mathrm{B} 2{ }^{\circledR}$ and with different rooftop greening. The values of emissions differ from one order of magnitude between both roofs (from 26 to $260 \mu \mathrm{g} / \mathrm{m}^{2}$ ) because of contrasting residence times, bituminous sealing membranes, microbial activities at the membrane surface and root intensity and their penetration into the membranes. Burkhardt et al. (2011) also investigated the leaching of mecoprop from roof at the semi-technical scale $\left(2.5 \mathrm{~m}^{2}\right)$. Cumulative emissions were $1 \mathrm{mg} / \mathrm{m}^{2}$ for Preventol $B 2^{\circledR}$ and $12 \mathrm{mg} / \mathrm{m}^{2}$ for Herbitect ${ }^{\circledR}$ ( $\mathrm{HE}$, half as concentrated as B2), which represent 0.04 and $0.2 \%$ of the initial amount, respectively. The ethylhexylester of mecoprop in product Herbitect ${ }^{\circledR}$ is less susceptible to hydrolysis than polyglycolester in B2, which means that the emissions of mecoprop in runoff from product Preventol B2 ${ }^{\circledR}$ are higher. Compared to emissions reported by Bucheli et al. (1998), higher emissions were observed because of the test procedure: Burkhardt et al. (2011) performed eleven sprinkling events of $5 \mathrm{~h}$ over 70 days, which corresponds to $1100 \mathrm{~mm}$ of water (annual rainfall in Zürich) and Bucheli et al. (1998) sprayed $18 \mathrm{~L} / \mathrm{m}^{2}$ of tap water on flat roofs within 30 min only once. Riechel et al. (2015) measured mecoprop release from a real green roof with bituminous membrane containing mecoprop and calculated leaching rates of $0.24 \mathrm{mg} / \mathrm{m}^{2}$.

So far, emissions of benzalkonium to runoff have been poorly documented but a two-part study was conducted to characterize and quantify the level of benzalkonium in runoff from treated roofs. The first part (Van de Voorde et al. 2012) is a laboratory scale study and the second one (Gromaire et al. 2015) a 1-year in-situ pilot scale study. Test benches, covered with old clay tiles or concrete tiles on which commercial de-mossing product was applied $\left(5900 \mathrm{mg} / \mathrm{m}^{2}\right)$, were exposed to natural weather conditions during 13 months. After $640 \mathrm{~mm}$ of rain, cumulative emissions from old clay tiles $\left(152 \mathrm{mg} / \mathrm{m}^{2}\right)$ were much lower than those from concrete tiles $\left(1683 \mathrm{mg} / \mathrm{m}^{2}\right)$ and represented only $2 \%$ of the initial amount, against $27 \%$ for concrete tiles. This result highlights once more the influence of the material. These roof scale data are valuable for simulating benzalkonium emissions, but no assessment has yet been done at the watershed scale and is hence needed.

Many data on emissions of biocides from building materials are reported in the literature even if they are scarcer for MIT, tebuconazole, mecoprop and benzalkoniums. Many leaching tests were performed following different protocols at different scales: lab scale, semi-technical scale, building scale and under lab conditions or natural weather conditions. As cumulative emissions depend on test procedures (e.g. exposure by immersion or spraying, time of exposure, amount of water, duration of the experiment, orientation of the specimen, etc.) and on specimens (nature of the material, initial quantity of biocides, age etc.), a high variability was observed. These differences highlight once again the difficulty of comparing values from studies that do not follow the same procedure. Standardized methods are therefore needed so that leachability can be compared between several materials. An interlaboratory study was conducted by Schoknecht et al. (2013) and showed that the procedure described in EN 16105 (CEN 2011) is suitable for investigating the leachability of active ingredient in coatings, as similar results were observed between and within laboratories. However, these methods only enable biocide emissions to be 
estimated under laboratory conditions, not under natural weather conditions, and hence introduce uncertainties to assess real biocide emissions from building materials in the environment. Indeed, as already mentioned in this review, many parameters can influence leaching of biocides. Natural weather conditions are difficult to reproduce because of their unpredictable nature. Another limit of the reported studies concerns the risk assessment. The different procedures could lead to an over- or underestimation of emissions and to the corresponding risk assessment. Only scarce studies assess the toxicity of the leachates though this would be a relevant tool for assessing potential environmental impact (Bandow et al. 2018). For instance, Vermeirssen et al. (2018) conducted ecotoxicity test on leachates and demonstrated that combining standardized leaching tests with standardized bioassays is a valuable tool to assess the environmental risk of biocide releases from façade renders and to rank the different materials according to potential ecotoxicity.

\subsubsection{Modelling studies}

The objectives of the modelling studies are (i) to understand the mechanism involved on a small scale, (ii) to generalize the emission data from small to larger scales, such as city or the watershed, and (iii) to assess the risk for aquatic ecosystems. A few studies developed diffusion-based models, as it was supposed to be the controlling mechanism of leaching. Wangler et al. (2012) and Styszko and Kupiec (2018) included dry periods in their models in order to allow biocide redistribution within the material. Results were in the range of experimental data from lab scale experiments. Also, several studies (Lupsea et al. 2013; Styszko et al. 2014; Bollmann et al. 2015a) described biocide partition between the material and the water as a major mechanism which controls leaching. Erich and Baukh (2016) took three mechanisms into account: water diffusion, biocide transfer to water and biocide diffusion. The first one was assumed to be the fastest. Then, two cases were distinguished: (i) biocide diffusion was the slowest mechanism and thus biocide emissions were proportional to the square root of water exposure time or (ii) transfer to water was the slowest mechanism and thus emissions were proportional to water exposure time. From these observations, Uhlig et al. (2019) proposed a mathematical approach in order to determine the mechanism controlling leaching at a given moment from experimental data (treated materials exposed to natural weather conditions). Desorption, diffusion and degradation processes were different for the three studied biocides (diuron, terbutryn and OIT), which led to different emission curves. Also, the authors suggested that changes in weather conditions might change mechanisms or factors controlling the release of biocides. Wittmer et al. (2011b) developed a model to simulate the losses of diuron from a façade in order to assess the significance of this phenomenon under realistic outdoor conditions on a small scale. The model is based on the sum of two exponential functions to simulate both a fast and a slow diffusion process. The model was based on the applied amounts of biocides in façade materials and on rainfall. However, the amount of rainfall that reaches façades and turns into runoff is difficult to predict as it depends on the rain intensity, the wind speed or the location of the building (Blocken and Carmeliet 2004; Blocken et al. 2009). The results showed that only a third of the initial amount was leached after the equivalent of 6 years of rainfall in the Swiss Plateau, which is consistent with experimental data on the lab scale. These examples underline the ability of models to simulate the emissions but also the complexity to calibrate numerous parameters and

mechanisms. Moreover, these models are limited and cannot be extrapolated to the city scale 
because (i) they imply too many processes to which biocides are subjected to allow rapid computation and (ii) they did not consider spatial variations. Coutu et al. (2012a; 2012b) developed therefore another type of model to simulate leaching of biocides (terbutryn, carbendazim and diuron) at the city scale. They used a two-region model: (i) the biocide in the façade and (ii) the biocide in the flow over the façade surface (Coutu et al. 2012a). Then, they coupled their model at the city scale with basin scale hydrologic and biocide transport submodels to simulate degradation, sorption or dilution into the separate storm sewer (Coutu et al. 2012b). The façade models were calibrated using the same experimental laboratory data of Burkhardt et al. (2011) as Wittmer et al. (2011b) and extrapolated at the city of Lausanne (Switzerland). The models allowed assessing the biocide emissions at the city scale (900 kg/y for Lausanne) and predicting the concentrations in the receiving river with an overall good match between calculated and experimental data. Generally, modeled concentrations were slightly underestimated. Thanks to this model, risk assessments were performed and showed a low probability of exceeding the predicted no effect concentrations (PNEC) values ( $9 \%$ for diuron, $5 \%$ for carbendazim and $0 \%$ for terbutryn).

Models are therefore valuable tools for assessing biocide loads that are discharged to runoff. Using such models could be a first step to risk assessments but it relies on the availability of many informations, such as the consumption data or sale volumes, the amount of rainfall available for façade leaching or the façade surface area, which are often not available. Moreover, the variability of watersheds and cities makes generalisation of models and risk assessments complex because of different land-uses and impervious surfaces, the age and the orientation of buildings, the weather conditions etc. (Gaylarde et al. 2011). Many uncertainties also remain: spatial variability of rainfall, particulate contamination for more hydrophobic biocides such as benzalkonium chlorides, variety of sewer discharges (stormwater discharges, combined sewer overflows and WWTP discharges during wet weather). Therefore, further research should be done to improve large-scale models with the objectives to complete and validate all data in order to calibrate, evaluate performance and recalibrate if necessary.

\subsubsection{Reduction of biocide releases from buildings during rain events}

The reported studies concerning leaching of biocides from building materials pointed out some solutions to reduce emissions at source, depending on construction type and product used. The comparison between the two products Preventol B2 ${ }^{\circledR}$ and Herbitect ${ }^{\circledR}$ (Burkhardt et al. 2011) demonstrates that improving product formulations with respect to the release of hazardous substances is an effective source control measure to reduce the impact of construction materials on receiving waters. As a result, the three main manufacturers of bituminous membranes in Switzerland no longer use product B2 and they have revised their formulations in order to obtain

the same leaching characteristics as HE. Another way to reduce the leaching of biocides from building materials is the encapsulation of biocides in polymer microspheres (Andersson et al. 2015; Nordstierna et al. 2010) or in the silica of the material (Edge et al. 2001), which slows down their release. Similarly, Wangler et al. (2012) showed that adding a top coating (paint) without biocide limits emissions and still protects the façade. Concerning roof treatment practices, Gromaire et al. (2015) suggested that de-mossing products should be used as a curative rather than a preventive treatment when needed. The dose must be reduced and adapted to the 
material (ceramic vs. concrete for tiles), the level of proliferation, and to the age of tiles (new tiles are less porous and thus emit more benzalkoniums). The choice of materials (e.g., silicone vs. acrylate renders) could constitute a solution to reduce emissions of biocides at source (Gromaire et al. 2015; Styszko et al. 2014). Wicke et al. (2015) reported the intensive uses of mecoprop in bituminous membranes, even if root protection is not required. In the light of these observations, the Senate of Berlin provided recommendations to avoid unnecessary emissions of this compound (SenStadtUm 2013).

\subsection{Mass balance}

In order to understand the fate of biocides during leaching, mass balances were performed between the initial mass of biocides, the remaining amount in the material and the emitted part into runoff (Schoknecht et al. 2009, 2013; Burkhardt et al. 2012; Wangler et al. 2012; Bollmann et al. 2016, 2017b). Indeed, biocides in building materials are exposed to environmental conditions and can be transformed over time by several processes, e.g. hydrolysis, biodegradation, direct and indirect photolysis (Fenner et al. 2013) and, in most cases, transformation products (TPS) are formed as a result of incomplete degradation (Hensen et al. 2018). TPs of some biocides are directly formed in the material itself by photodegradation, which is the most common degradation process (Burkhardt et al. 2012; Breuer et al. 2012; Luo et al. 2013; Bollmann et al. 2016, 2017b; Hensen et al. 2018). Identified photodegradation products are reported in table 3.

Several studies reported a mass balance deficit: the amount released and the amount remaining in the material did not correspond to the initial quantity of biocides in the material (Schoknecht et al. 2009, 2013; Burkhardt et al. 2012; Wangler et al. 2012; Bollmann et al. 2016, 2017b). In particular, a significant mass balance deficit was observed for easily photodegradable compounds such as IPBC, OIT, DCOIT or terbutryn. Wangler et al. (2012) found a deficit of 55\%, $62 \%$ and $43 \%$ for OIT, DCOIT and IPBC, respectively, on a lab scale. Burkhardt et al. (2012) and Bollmann et al. (2016, 2017b) exposed panels to natural weather conditions and reported a deficit of $35 \%$ for terbutryn and more than $70 \%$ for OIT, as shown in figure 1 . In order to explain these deficits, the presence of TPs both in materials and runoff were investigated. 6 out of the 15 searched TPs ( 8 for terbutryn and 7 for OIT) have been detected in the façade and runoff. Cumulative emissions of TPs ranged from 8 to $40 \mathrm{mg} / \mathrm{m}^{2}$ for terbutryn and from 2 to $75 \mathrm{mg} / \mathrm{m}^{2}$ for OIT. A peak in the emission of the major OIT TP, octylamine, was detected in early summer because of higher UV-degradation at this time of year. The quantity of TPs that leached represented 2 to $4 \%$ and the quantity of TPs remaining in panels was twice as high as these values. The majority of the TPs remained in the material and did not leached out. However, the older the material, the more TPs might undergo leaching. Burkhardt et al. (2011) quantified the descyclopropyl-cybutryn (M1), a TP of both cybutryn and terbutryn, in runoff from spiked panels exposed to natural weather conditions. They reported low M1 concentration just after application followed by a progressive increase with time until it finally exceeds cybutryn or terbutryn concentration. 
Table 3. Identified phototransformation products of biocides

\begin{tabular}{|c|c|c|c|c|c|}
\hline Biocides & $\begin{array}{l}\text { Abbrevi } \\
\text { ation }\end{array}$ & Phototransformation products & $\begin{array}{l}\text { Chemical } \\
\text { formula }\end{array}$ & $\begin{array}{l}\text { Precurs } \\
\text { or ion } \\
(\mathrm{m} / \mathrm{z})\end{array}$ & Références \\
\hline Carbendazim & & 2-aminobenzimidazole & $\mathrm{C}_{7} \mathrm{H}_{7} \mathrm{~N}_{3}$ & & $\begin{array}{c}\text { Urbanczyk et al. } \\
(2019 b)\end{array}$ \\
\hline CMIT & & \multirow{2}{*}{ Acetic and formic acids } & & & \multirow{2}{*}{$\begin{array}{c}\text { Krzeminski et al. } \\
(1975)\end{array}$} \\
\hline \multirow{6}{*}{ DCOIT } & & & & & \\
\hline & & N-octanal & & 128,00 & \multirow{5}{*}{$\begin{array}{l}\text { Sakkas et al. } \\
\qquad(2002)\end{array}$} \\
\hline & & $\mathrm{N}$-octyl isocyanate & & & \\
\hline & & $\mathrm{N}$-cotyl amine & & 129,00 & \\
\hline & & $\mathrm{N}$-octyl actamide & & 171,00 & \\
\hline & & $\mathrm{N}$-n-octyl oxamic acid & & 201,00 & \\
\hline \multirow{11}{*}{ OIT } & TP-214 & 2-octylthiazol-2(3 H)-one & $\mathrm{C}_{11} \mathrm{H}_{19} \mathrm{NOS}$ & 214,13 & \multirow{8}{*}{$\begin{array}{l}\text { Bollmann et al. } \\
\qquad(2017 b)\end{array}$} \\
\hline & TP-158 & N-octylformamide & $\mathrm{C}_{9} \mathrm{H}_{19} \mathrm{NO}$ & 158,15 & \\
\hline & TP-184a & $\mathrm{N}$-octylprop-2-enamide & $\mathrm{C}_{11} \mathrm{H}_{21} \mathrm{NO}$ & 184,17 & \\
\hline & TP-172 & N-octylacetamide & $\mathrm{C}_{10} \mathrm{H}_{21} \mathrm{NO}$ & 172,17 & \\
\hline & TP-130 & Octylamine & $\mathrm{C}_{8} \mathrm{H}_{19} \mathrm{~N}$ & 130,16 & \\
\hline & TP-216 & $\mathrm{N}$-octyl malonamic acid & $\mathrm{C}_{11} \mathrm{H}_{21} \mathrm{NO}_{3}$ & 216,16 & \\
\hline & TP-198 & $\begin{array}{l}\text { 2-octyl-1,2-oxazol-3(2 H)-on* } \\
\text { 3-octyl-1,3-oxazol-2(3 H)-one }\end{array}$ & & 198,15 & \\
\hline & TP-184b & N-ethenyl-N-octylformamide ${ }^{*}$ & $\mathrm{C}_{11} \mathrm{H}_{21} \mathrm{NO}^{*}$ & 184,17 & \\
\hline & TP-188 & & & 188,16 & \multirow{3}{*}{$\begin{array}{l}\text { Bollmann et al. } \\
\text { (2017b) } \\
\text { Hensen et al. } \\
\text { (2018) }\end{array}$} \\
\hline & TP-182 & & & 182,15 & \\
\hline & TP-144 & & & 144,14 & \\
\hline \multirow{3}{*}{ Diuron } & TP-219 & $\begin{array}{l}\text { 1-(3,4-dichlorophenyl)-3-methylurea } \\
\text { (DCPMU) }\end{array}$ & $\begin{array}{c}\mathrm{C}_{0} \mathrm{H}_{8} \mathrm{Cl}_{2} \mathrm{~N}_{2} \\
\mathrm{O}\end{array}$ & 219,01 & \multirow{3}{*}{$\begin{array}{c}\text { Hensen et al. } \\
\text { (2018) } \\
\text { Urbanczyk et al. } \\
\text { (2019b) }\end{array}$} \\
\hline & TP-215a & $\begin{array}{l}\text { 3-(3-chloro-4-hydroxyphenyl)-1,1- } \\
\text { dimethylurea }\end{array}$ & $\begin{array}{c}\mathrm{C}_{9} \mathrm{H}_{10} \mathrm{ClN} \\
\mathrm{O} \\
\end{array}$ & 215,06 & \\
\hline & TP-215b & $\begin{array}{l}\text { 3-(4-chloro-3-hydroxyphenyl)-1,1- } \\
\text { dimethylurea }\end{array}$ & $\begin{array}{c}\mathrm{C}_{9} \mathrm{H}_{12} \mathrm{ClN}_{2} \\
\mathrm{O}_{2}\end{array}$ & 215,06 & \\
\hline Cybutryn & & & & & Hensen et al. \\
\hline \multirow{11}{*}{ Terbutryn } & TP-214 & Desethyl-terbutryn (M1) & $\mathrm{C}_{8} \mathrm{H}_{15} \mathrm{~N}_{5} \mathrm{~S}$ & 214,11 & $\begin{array}{c}\text { (2018) } \\
\text { Bollmann et al. } \\
(2016)\end{array}$ \\
\hline & TP-258 & Terbutryn sulfoxide & $\begin{array}{c}\mathrm{C}_{10} \mathrm{H}_{19} \mathrm{~N}_{5} \mathrm{O} \\
\mathrm{S}\end{array}$ & 258,14 & \multirow{7}{*}{$\begin{array}{l}\text { Bollmann et al. } \\
\qquad(2016)\end{array}$} \\
\hline & TP-196 & Desthiomethyl-terbutryn & $\mathrm{C}_{9} \mathrm{H}_{17} \mathrm{~N}_{5}$ & 196,16 & \\
\hline & TP-168 & Desthiomethyl-desethyl-terbutryn & $\mathrm{C}_{7} \mathrm{H}_{13} \mathrm{~N}_{5}$ & 168,13 & \\
\hline & TP-140 & Desthiomethyl-desbutyl-terbutryn & $\mathrm{C}_{6} \mathrm{H}_{9} \mathrm{~N}_{5}$ & 140,09 & \\
\hline & TP-212 & 2-hydroxy-terbutryn & $\mathrm{C}_{9} \mathrm{H}_{17} \mathrm{~N}_{5} \mathrm{O}$ & 212,15 & \\
\hline & TP-184 & Desethyl-2-hydroxy-terbutryn & $\mathrm{C}_{9} \mathrm{H}_{13} \mathrm{~N}_{5} \mathrm{O}$ & 184,12 & \\
\hline & TP-226 & Terbumeton & $\mathrm{C}_{10} \mathrm{H}_{19} \mathrm{~N}_{5} \mathrm{O}$ & 226,17 & \\
\hline & TP-186 & & $\mathrm{C}_{6} \mathrm{H}_{11} \mathrm{~N}_{5} \mathrm{~S}$ & 186,10 & \multirow{3}{*}{$\begin{array}{l}\text { Hensen et al. } \\
\qquad(2018)\end{array}$} \\
\hline & TP-210 & & $\mathrm{C}_{9} \mathrm{H}_{15} \mathrm{~N}_{5} \mathrm{O}$ & 210,14 & \\
\hline & TP-256 & & $\begin{array}{c}\mathrm{C}_{10} \mathrm{H}_{18} \mathrm{~N}_{5} \mathrm{~S} \\
\mathrm{O}\end{array}$ & 256,16 & \\
\hline
\end{tabular}

\footnotetext{
*assumption
} 
For TP investigation, two different cases are reported: (i) mass balance is closed with TPs and (ii) mass balance is not closed even if TPs were taken into account, as illustrated by the figure 1. Indeed, in the case of terbutryn, the mass balance was closed with eight TPs but it was not the case for OIT, although seven TPs were included. This remaining deficit was attributed to vaporisation (octylamine is considerably more volatile than OIT), undetected TPs or complete mineralization via acetic and formic acids (Bollmann et al. 2016, 2017b).

Recently, Urbanczyk et al. (2019b) showed that the photodegradation of biocides (OIT, terbutryn, diuron and carbendazim) was much slower in presence of pigments in paints (e.g., $\mathrm{TiO}_{2}, \alpha-\mathrm{Fe}_{2} \mathrm{O}_{3}, \mathrm{Fe}_{3} \mathrm{O}_{4}$ ) because of their interaction with light. The fastest photodegradation was observed for OIT contrary to carbendazim, which was not significantly photolyzed. Little difference in the degradation rates was observed between the three pigments but different TP patterns were observed for both terbutryn and OIT.

This section pointed out that the investigation of biocide emissions from building materials should integrate the monitoring of TPs to assess mass balances. Photodegradation plays a key role in the TP production. However, even if known TPs are taken into account, mass balances are still not closed for a majority of biocides, such as OIT. Further work is required to elucidate the processes involved in TP production, to identify missing TPs and to prove their complete mineralization or vaporization, if appropriate. High-resolution mass spectrometry and nontargeted approaches are relevant tools for the identification of molecular structures of TPs (Bletsou et al. 2015; Bollmann et al. 2016, 2017b). However, physico-chemical properties, ecotoxicity and environmental fate of TPs are often unknown (Hensen et al. 2018), thus significantly limiting risk assessment of biocides from building materials.

\section{Transport of biocides and occurrence in the aquatic environment}

The previous section highlighted that biocides and TPs are released from building materials in runoff. They can be discharged into surface water or contaminate groundwater via infiltration processes. Pathways of biocides from buildings to receiving environment are many and varied, including WWTP effluents and combined sewer overflows in the case of combined sewer systems, or stormwater discharges in the case of separate sewer systems. In this section, levels of concentration of biocides in urban discharges during dry and wet weather conditions and surface water are reviewed. The values reported are compared to regulatory threshold for drinking water, groundwater and surface waters along with ecotoxicological values in order to assess the potential impact of discharges to receiving waters. To our knowledge, no study reported the level of zinc pyrithione contamination in freshwater, stormwater or WWTP waters. This compound is difficult to analyse and to quantify in water because of possible trans-chelation with other metals, such as copper or iron, which forms more stable complexes (Thomas 1999; Bones et al. 2006). 


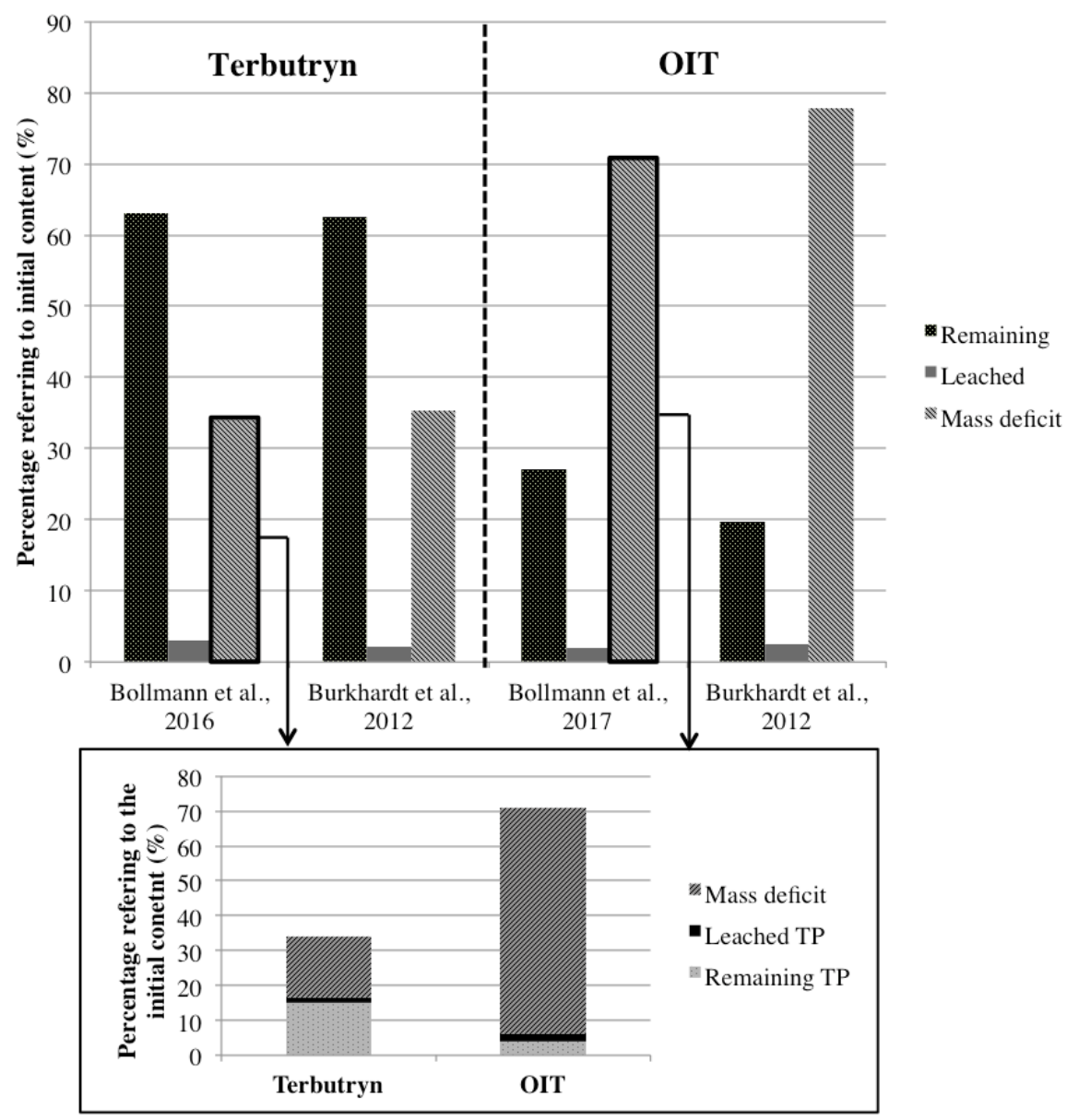

Fig. 1 Mass balance (\%) of terbutryn and OIT from artificial walls coated with acrylate renders in which biocides were added (seven biocides in the study of Burkhardt et al. (2012) and just the biocide of interest in the other two studies). Panels were exposed from one year to 19 months to natural weather conditions according to Bollmann et al. (2016), Bollmann et al. (2017b) and Burkhardt et al. (2012). Top charts did not include TPs in mass balances contrary to bottom chart, in which eight TPs of terbutryn and seven TPs of OIT (from photolysis) were included (adapted from Bollmann et al. (2016) and Bollmann et al. (2017b)).

\subsection{Discharge to receiving waters}

\subsubsection{Façade runoff}

Concentrations measured in façade runoff were often found in the range of a few $\mathrm{mg} / \mathrm{L}$ at the beginning of the experiment and about tens of $\mu \mathrm{g} / \mathrm{L}$ at the end. For example, in Burkhardt et al. (2011), concentrations of diuron and carbendazim in runoff were 7 and $0.7 \mathrm{mg} / \mathrm{L}$ respectively at the beginning of the experiment, under laboratory conditions. After the equivalent of 6 years of rainfall in the Swiss Plateau, concentrations were up to 2 orders of magnitude lower with $70 \mu \mathrm{g} / \mathrm{L}$ for diuron and $40 \mu \mathrm{g} / \mathrm{L}$ for carbendazim. Under natural weather conditions, Burkhardt et al. (2012) reported concentrations of diuron in façade runoff between 10 and $25 \mathrm{mg} / \mathrm{L}$ in the first months and close to $2 \mathrm{mg} / \mathrm{L}$ after one year of exposure. Terbutryn was detected in a similar amount in Burkhardt et al. (2012) and Bollmann et al. (2016) studies, from 1-5 mg/L in the first months to less than $1 \mathrm{mg} / \mathrm{L}$ after one year-exposure. The M1 TP of terbutryn and cybutryn was 
also detected at up to $12 \mathrm{mg} / \mathrm{L}$ in Burkhardt et al. (2012) study. Bollmann et al. (2016) detected the four main TPs of terbutryn (i.e., terbutryn sulfoxide, 2-hydroxy-terbutryn, desethyl-terbutryn and desethyl-2-hydroxy-terbutryn) in façade runoff at concentrations ranging from 0.05 to $1.5 \mathrm{mg} / \mathrm{L}$. Concentrations of OIT ranged from less than $20 \mu \mathrm{g} / \mathrm{L}$ to $14 \mathrm{mg} / \mathrm{L}$ and six out the seven studied TPs were detected in most of the samples, at up to $8.8 \mathrm{mg} / \mathrm{L}$ for $\mathrm{N}$-octyl oxamic acid (Bollmann et al. 2017b).

In roof runoff, concentrations of mecoprop varied from 1.5 to $4 \mu \mathrm{g} / \mathrm{L}$ and very high concentrations $(500 \mu \mathrm{g} / \mathrm{L})$ were measured after a long dry period in summer. Similar concentrations were measured by Burkhardt et al. (2011), from 1-10 $\mu \mathrm{g} / \mathrm{L}$ to $400 \mu \mathrm{g} / \mathrm{L}$. For benzalkoniums, Van de Voorde et al. (2012) measured concentrations in roof runoff (sum of C12 and C14 benzalkoniums) ranging from 5 to $30 \mathrm{mg} / \mathrm{L}$ immediately after treatment. It took 5 to 7 months for the concentration to drop down below the EC50 value for fish $(280 \mu \mathrm{g} / \mathrm{L}$ (USEPA 2006)). After $640 \mathrm{~mm}$ of rainfall (i.e., the annual rainfall in Paris), concentrations in runoff remained above $4 \mu \mathrm{g} / \mathrm{L}$, which is one order of magnitude higher than the PNEC value of $0.415 \mu \mathrm{g} / \mathrm{L}$ (European Parliament and Council 2015c).

\subsubsection{Stormwater}

Only a few studies measured concentrations of biocides in separate stormwater pipe system or combined sewers overflows (CSOs), which are a mixture of stormwater and wastewater. The biocide concentrations in stormwater and CSOs are reported in table 4. Most of these studies focused on biocides also used as PPP (phenylureas, triazines, carbendazim, mecoprop, etc.). In stormwater, concentrations ranged from tens of $\mathrm{ng} / \mathrm{L}$ to a few $\mu \mathrm{g} / \mathrm{L}$. According to table 4 , diuron, carbendazim, mecoprop and isoproturon have been detected with the highest concentrations, up to $12 \mu \mathrm{g} / \mathrm{L}$ in the case of diuron. In the frame of the OgRe project (Wicke et al. 2015), the quality of stormwater from different catchments (old buildings, new buildings, commercial area, residential area and road area) was monitored during one year (table 4). Higher concentrations of mecoprop, carbendazim, diuron and terbutryn were measured in the catchment with old buildings, because of recent refurbishment. A strong correlation was established between diuron and carbendazim concentrations and the number of façades coated with render. Another correlation was established between terbutryn concentrations and the roof surface in the catchment because of its use in roof paints while a lowest correlation with the number of façades coated with render was observed. Mecoprop was detected in all the studied catchments because of its use in bituminous membranes. It is interesting to note that concentrations in building runoff are in the $\mathrm{mg} / \mathrm{L}$ range, which suggests significant dilution of biocides in stormwater with runoff from other impervious surfaces, or infiltration in case of pervious surfaces. Burkhardt et al. (2011) examined the different pathway of biocides from buildings to stormwater receiving waters and compared the occurrence of terbutryn, carbendazim, diuron and mecoprop in building runoff and at three levels of the stormwater sewer: (1) one 0.5 ha subcatchment included in (2) a $11 \mathrm{ha}$ subcatchment and (3) at the discharge into a small river. Diuron was diluted between the building runoff and the discharge. For other compounds, concentrations were in the same order of magnitude at the three levels. At the discharge to the receiving waters, median concentrations were about $100 \mathrm{ng} / \mathrm{L}$ for both biocides but could reach 1.8, 1.1 and $10 \mu \mathrm{g} / \mathrm{L}$ for terbutryn, carbendazim and mecoprop respectively. 
Table 4. Concentrations in $\mathrm{ng} / \mathrm{L}$ ( $\min -\max$ ) of biocides used in building materials in stormwater (sampling in separate stormwater sewer pipes) and combined sewer overflows

\begin{tabular}{|c|c|c|c|c|}
\hline Biocides & $\begin{array}{c}\text { Concentrations } \\
\text { in stormwater } \\
(\mathrm{ng} / \mathrm{L})\end{array}$ & $\begin{array}{l}\text { Concentrations } \\
\text { in combined } \\
\text { sewer } \\
\text { overflows } \\
\text { (ng/L) }\end{array}$ & Country & Reference \\
\hline Carbendazim & $\begin{array}{l}<20-1500 \\
45 \\
<3-1568\end{array}$ & $15-42$ & $\begin{array}{l}\text { Germany } \\
\text { Denmark } \\
\text { France } \\
\text { Germany }\end{array}$ & $\begin{array}{l}\text { Wicke et al. (2015) } \\
\text { Bollmann et al. (2015) } \\
\text { Gasperi et al. (2013) } \\
\text { Launay et al. (2016) }\end{array}$ \\
\hline BIT & $\begin{array}{l}<4 \\
<30-1600\end{array}$ & & $\begin{array}{l}\text { France } \\
\text { Germany }\end{array}$ & $\begin{array}{l}\text { Gasperi et al. (2013) } \\
\text { Wicke et al. (2015) } \\
\end{array}$ \\
\hline OIT & $\begin{array}{l}<4 \\
<30-60 \\
<0.77-67\end{array}$ & & $\begin{array}{l}\text { France } \\
\text { Germany } \\
\text { Germany }\end{array}$ & $\begin{array}{l}\text { Gasperi et al. (2013) } \\
\text { Wicke et al. (2015) } \\
\text { Hensen et al. (2018)* } \\
\end{array}$ \\
\hline Diuron & $\begin{array}{l}<10-55 \\
<5-11997 \\
30-1750 \\
40-80 \\
<30-600 \\
<0.39-4.9\end{array}$ & $\begin{array}{l}480 \\
90-1600 \\
\\
68-681 \\
43-81\end{array}$ & $\begin{array}{l}\text { Denmark } \\
\text { France } \\
\text { France } \\
\text { France } \\
\text { Germany } \\
\text { Germany } \\
\text { Switzerland } \\
\text { Germany }\end{array}$ & $\begin{array}{l}\text { Birch et al. (2011) } \\
\text { Gasperi et al. (2008, } \\
\text { 2013) } \\
\text { Zgheib (2009) } \\
\text { Bressy (2010) } \\
\text { Wicke et al. (2015) } \\
\text { Launay et al. (2016) } \\
\text { Burkhardt et al. (2007) } \\
\text { Hensen et al. (2018)* }\end{array}$ \\
\hline Isoproturon & $\begin{array}{l}<10-44 \\
<5-1017 \\
<10-140 \\
50 \\
<30-120\end{array}$ & $\begin{array}{l}200 \\
<60 \\
25-180\end{array}$ & $\begin{array}{l}\text { Denmark } \\
\text { France } \\
\text { France } \\
\text { France } \\
\text { Germany } \\
\text { Germany }\end{array}$ & $\begin{array}{l}\text { Birch et al. (2011) } \\
\text { Gasperi et al. (2008, } \\
\text { 2013) } \\
\text { Zgheib (2009) } \\
\text { Bressy (2010) } \\
\text { Wicke et al. (2015) } \\
\text { Launay et al. (2016) }\end{array}$ \\
\hline Cybutryn & $\begin{array}{l}52 \\
<4 \\
<20-20\end{array}$ & & $\begin{array}{l}\text { Denmark } \\
\text { France } \\
\text { Germany }\end{array}$ & $\begin{array}{l}\text { Bollmann et al. (2015b) } \\
\text { Gasperi et al. (2013) } \\
\text { Wicke et al. (2015) }\end{array}$ \\
\hline Terbutryn & $\begin{array}{l}<4 \\
<10-360 \\
1-160\end{array}$ & $\begin{array}{l}<60-160 \\
9-210\end{array}$ & $\begin{array}{l}\text { France } \\
\text { Germany } \\
\text { Germany } \\
\text { Germany }\end{array}$ & $\begin{array}{l}\text { Gasperi et al. (2008, } \\
\text { 2013) } \\
\text { Wicke et al. (2015) } \\
\text { Launay et al. (2016) } \\
\text { Hensen et al. (2018)* }\end{array}$ \\
\hline Terbuthylazine & $\begin{array}{l}<10 \\
<30-260\end{array}$ & 200 & $\begin{array}{l}\text { Denmark } \\
\text { Germany }\end{array}$ & $\begin{array}{l}\text { Birch et al. (2011) } \\
\text { Wicke et al. (2015) }\end{array}$ \\
\hline
\end{tabular}




\begin{tabular}{|l|l|l|l|l|}
\hline Propiconazole & 40 & $<60-210$ & $\begin{array}{l}\text { France } \\
\text { France }\end{array}$ & $\begin{array}{l}\text { Bressy (2010) } \\
\text { Gasperi et al. (2013) }\end{array}$ \\
\hline Tebuconazole & $<20-90$ & & Germany & Wicke et al. (2015) \\
\hline Mecoprop & $\begin{array}{l}<20-6900 \\
<1-10\end{array}$ & $100-378$ & $\begin{array}{l}\text { Germany } \\
\text { France } \\
\text { Germany }\end{array}$ & $\begin{array}{l}\text { Wicke et al. (2015) } \\
\text { Gasperi et al. (2013) } \\
\text { Launay et al. (2016) }\end{array}$ \\
\hline
\end{tabular}

* Sampling in swales

\subsubsection{Wastewater during dry and wet weather conditions}

Concentrations in untreated and treated wastewater are useful (i) to determine the origin of biocides between runoff from buildings and domestic uses in the case of combined sewer networks and (ii) to compare the pathways of biocides into receiving waters (WWTP effluents vs. urban discharges during wet weather). Data on the occurrence of biocides in WWTP influents and effluents from recent studies are reported in figure 2 . They are quite numerous for biocides also used as a PPP, such as phenylureas and triazines. Influent and effluent concentrations were of the same order of magnitude, ranging from a few $\mathrm{ng} / \mathrm{L}$ to hundreds of $\mathrm{ng} / \mathrm{L}$ (figure 2 ). It is interesting to note that concentrations in effluents sometimes exceeded those in influents, particularly for phenylureas, carbendazim and mecoprop. Wick et al. (2010) measured 26 biocides in two WWTPs. For most of them, concentrations in effluent were higher or of the same order of magnitude than those in influent. For example, diuron was detected at 23-68 ng/L (WWTP 1-WWTP 2) in influents and at 25-182 ng/L in effluents; mecoprop was detected at 252$37 \mathrm{ng} / \mathrm{L}$ in influents and at 203-72 ng/L in effluents; carbendazim was detected at 41-143 ng/L in influents and $48-88 \mathrm{ng} / \mathrm{L}$ in effluents. Likewise, Guillossou et al. (2019) measured higher concentrations of diuron in effluents $(42 \mathrm{ng} / \mathrm{L})$ than in influents $(36 \mathrm{ng} / \mathrm{L})$ but with a significant variability. High concentrations of permethrin (up to $425 \mathrm{ng} / \mathrm{L}$ ) compared to the other biocides were reported in influents in two studies (Kupper et al. 2006; Gómez et al. 2007). This could be explained by its very widespread use as an insecticide (human and veterinary pediculicide (Başer et al. 2003), mothproofing on wool (Friedman et al. 1979; Ingham et al. 2012)). Figure 2 reveals a significant variability for a given compound in influents $(I)$ and effluents $(E)$, explained by the size of the watershed where the WWTP was located (from 1,500 to 1,000,000 inhabitants), the type of treatments, the sewer system (combined or separate), the local use and consumption of biocides or different weather conditions (Wittmer et al. 2010).

Bollmann et al. (2014a) compared the concentrations of 13 biocides (triazines, carbamates, isothiazolinones, phenylureas, triazoles and mecoprop) in wastewater during dry and wet weather conditions for 5 urban WWTPs in Denmark and Sweden. Most biocides were emitted during both wet and dry weather conditions, with the exception of mecoprop and isoproturon, which were only observed during wet weather conditions. Terbutryn, carbendazim and diuron were mostly emitted during rainy weather while tebuconazole inputs were similar for both weather conditions. 
Few data are available for quaternary ammonium compounds (QACs) in WWTPs. Concentrations measured in influents during dry weather ranged from a few $\mu \mathrm{g} / \mathrm{L}$ to hundreds of $\mu \mathrm{g} / \mathrm{L}$ (table 5), depending greatly on local activities (Kreuzinger et al. 2007) since QACs are extensively used in hospitals or laundry products. Concentrations were lower in effluents, from hundreds of $\mathrm{ng} / \mathrm{L}$ to a few $\mu \mathrm{g} / \mathrm{L}$. Only 5 studies concern isothiazolinones in table 5 . However, sometimes, the analytical protocols did not allow their detection and their quantitation (LOQ) at trace levels: LOQ were as high as $100 \mathrm{ng} / \mathrm{L}$ (Wick et al. 2010) and the limits of detection (LOD) $85 \mathrm{ng} / \mathrm{L}$ (Rafoth et al. 2007). Rafoth et al. (2007) detected concentrations exceeding $1 \mu \mathrm{g} / \mathrm{L}$ in WWTP influents but other publications have reported lower levels (a few $\mathrm{ng} / \mathrm{L}$ ) or did not detect isothiazolinones in untreated or treated wastewater (table 5).

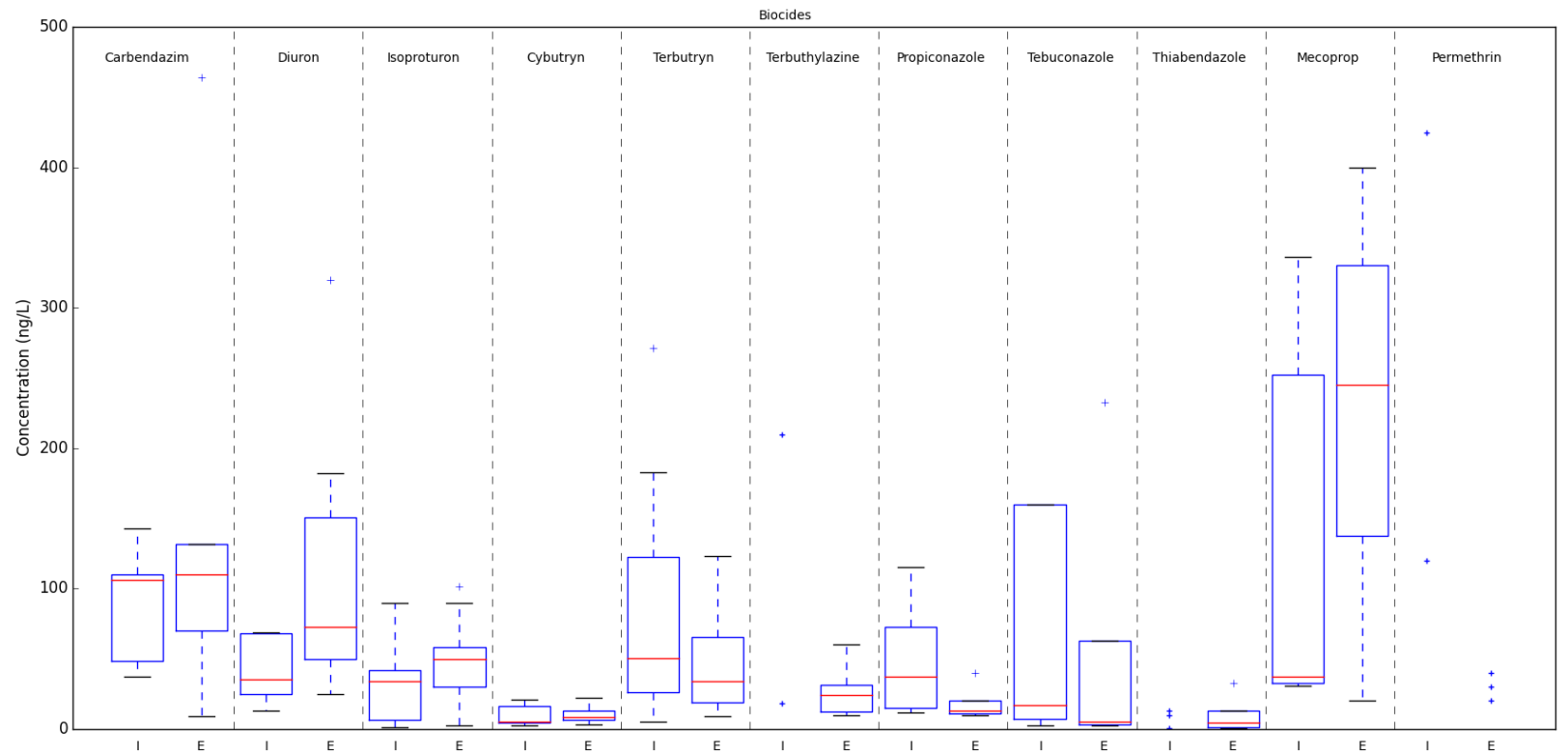

Fig. 2 Concentrations (ng/L) of biocides also used as PPP in influents and effluents of WWTP (Öllers et al. 2001; Kupper et al. 2006; Burkhardt et al. 2007; Gómez et al. 2007; Kahle et al. 2008; Bartelt-Hunt et al. 2009; Benvenuto et al. 2010; Morasch et al. 2010; Singer et al. 2010; Stamatis et al. 2010; Wick et al. 2010; Chen et al. 2012; Clara et al. 2012; Gros et al. 2012; Barco-Bonilla et al. 2013; Campo et al. 2013; Margot et al. 2013; Masiá et al. 2013; Luft et al. 2014; Bollmann et al. 2014a; Mailler et al. 2015; Launay et al. 2016; Peris-Vicente et al. 2016; Wluka et al. 2016). I: influents and E: effluents. These box plots were developed with average values available in the literature. Red line corresponds to the median value. The box corresponds to the first and the third quartiles. The bars linked to the box by dotted lines are the first and ninth deciles. Single crosses are extreme values or all values when data were not sufficient to create a box plot. 
Table 5. Concentrations ( $\mu \mathrm{g} / \mathrm{L}$ ) of QACs and isothiazolinones in WWTP influents and effluents

\begin{tabular}{|c|c|c|c|c|}
\hline Biocides & $\begin{array}{l}\text { Concentration } \\
\mathrm{s} \text { in WWTP } \\
\text { influent }(\mu \mathrm{g} / \mathrm{L})\end{array}$ & $\begin{array}{l}\text { Concentration } \\
\mathrm{s} \text { in WWTP } \\
\text { effluent }(\mu \mathrm{g} / \mathrm{L})\end{array}$ & Country & References \\
\hline $\begin{array}{l}\Sigma \text { Benzalkonium } \\
\text { (C12-C18) }\end{array}$ & $\begin{array}{l}22.4-306.8 \\
<0.006-3458 \\
38.2-251.9 \\
420 \\
<0.008-3.72\end{array}$ & $\begin{array}{l}0.088-1.6 \\
0.1-6.6 \\
0.192-3.5 \\
<10\end{array}$ & $\begin{array}{l}\text { Austria } \\
\text { Austria } \\
\text { Austria } \\
\text { France } \\
\text { USA }\end{array}$ & $\begin{array}{l}\text { Clara et al. (2007) } \\
\text { Kreuzinger et al. (2007) } \\
\text { Martínez-Carballo et al. (2007) } \\
\text { Deborde et al. (2016) } \\
\text { Ferrer and Furlong (2001) }\end{array}$ \\
\hline DDAC (C10) & $\begin{array}{l}13-200 \\
<0.006-210 \\
13-41 \\
46-930\end{array}$ & $\begin{array}{l}0.06-0.79 \\
0.024-0.85 \\
0.004-0.85 \\
<30\end{array}$ & $\begin{array}{l}\text { Austria } \\
\text { Austria } \\
\text { Austria } \\
\text { France }\end{array}$ & $\begin{array}{l}\text { Clara et al. (2007) } \\
\text { Kreuzinger et al. (2007) } \\
\text { Martínez-Carballo et al. (2007) } \\
\text { Deborde et al. (2016) }\end{array}$ \\
\hline BIT & $\begin{array}{l}<0.1 \\
1.7-3.2 \\
<0.0022 \\
<0.8\end{array}$ & $\begin{array}{l}<0.05 \\
N D^{*} \\
<0.0012\end{array}$ & $\begin{array}{l}\text { Germany } \\
\text { Germany } \\
\text { China } \\
\text { Denmark }\end{array}$ & $\begin{array}{l}\text { Wick et al. (2010) } \\
\text { Rafoth et al. (2007) } \\
\text { Chen et al. (2012) } \\
\text { Bollmann et al. (2014a) }\end{array}$ \\
\hline CMIT & & $<0.03$ & $\begin{array}{l}\text { Netherlan } \\
\text { ds }\end{array}$ & Speksnijder et al. (2010) \\
\hline DCOIT & $\begin{array}{l}<0.01 \\
N D^{*} \\
0.0055-0.0061 \\
<0.001\end{array}$ & $\begin{array}{l}<0.005 \\
N D^{*} \\
0.0034-0.0064\end{array}$ & $\begin{array}{l}\text { Germany } \\
\text { Germany } \\
\text { China } \\
\text { Denmark }\end{array}$ & $\begin{array}{l}\text { Wick et al. (2010) } \\
\text { Rafoth et al. (2007) } \\
\text { Chen et al. (2012) } \\
\text { (Bollmann et al. 2014a) }\end{array}$ \\
\hline MIT & & $<0.04$ & $\begin{array}{l}\text { Netherlan } \\
\text { ds }\end{array}$ & (Speksnijder et al. 2010) \\
\hline OIT & $\begin{array}{l}<0.01-0.012 \\
N D^{*} \\
0.0021-0.0025 \\
<0.2\end{array}$ & $\begin{array}{l}<0.005 \\
N D^{*} \\
0.0004-0.0006\end{array}$ & $\begin{array}{l}\text { Germany } \\
\text { Germany } \\
\text { China } \\
\text { Denmark }\end{array}$ & $\begin{array}{l}\text { (Wick et al. 2010) } \\
\text { (Rafoth et al. 2007) } \\
\text { (Chen et al. 2012) } \\
\text { (Bollmann et al. 2014b) }\end{array}$ \\
\hline
\end{tabular}

* No LOD value is provided in the paper

\subsubsection{Discussion on biocide pathways into receiving waters}

Comparing concentrations in both matrices is interesting to assign sources (households or leaching from buildings). For most biocides, concentrations in stormwater, CSOs and wastewater are in the same order of magnitude. This means, that urban discharges in dry and wet weather conditions, are likely to contaminate the receiving waters. For some biocides (carbendazim, terbutryn, terbuthylazine), concentrations in CSOs are similar to those in wastewater, showing that household sources may be equivalent to those from buildings. For a few compounds (diuron, isoproturon, propiconazole, mecoprop), concentrations in CSOs are higher than the ones in wastewater. Consequently buildings appear to be the main source of these biocides in receiving waters. Although comparing concentrations is a first approach to assess the contribution of both 
pathways, comparing mass loads would be more relevant. According to the authors' knowledge, the OgRe project (Wicke et al. 2015) was the first one to estimate biocide loads from Berlin stormwater discharged to natural waters. Loads of mecoprop were estimated at $106 \mathrm{~kg} / \mathrm{y}$, those of carbendazim at $10 \mathrm{~kg} / \mathrm{y}$ and those for terbutryn and diuron at less than $10 \mathrm{~kg} / \mathrm{y}$. This work has to be pursued further with more biocides and extended to other European cities, as land-use could be different.

\subsection{Occurrence of biocides in rivers and groundwater}

\subsubsection{Rivers}

Table 6 shows concentrations in surface water of some biocides of interest. Most of the biocides that were measured in surface water were quantified worldwide during sampling campaigns not specifically devoted to rain events. Concentrations generally range from a few $\mathrm{ng} / \mathrm{L}$ to tens of $\mathrm{ng} / \mathrm{L}$. However, diuron, isoproturon, terbuthylazine, permethrin and mecoprop were detected at significantly higher concentrations, i.e., up to 8.6, 5.5, 12.6, 1.7 and $1.8 \mu \mathrm{g} / \mathrm{L}$, respectively. Data is still lacking for some other biocides that are not reported in table 6 , such as isothiazolinones, QAC or zinc pyrithione. Only a few studies have reported concentrations of QAC in surface water, results ranged from a few $\mathrm{ng} / \mathrm{L}$ to up to $55 \mu \mathrm{g} / \mathrm{L}$ according to Ding and Liao (2001), Ferrer and Furlong (2001) and Kreuzinger et al. (2007). Similarly, there has been little investigation on isothiazolinones in environmental compartments. Concentrations are often below LOD or LOQ (Rafoth et al. 2007; Speksnijder et al. 2010; Wick et al. 2010; Chen et al. 2012). However, Baranowska and Wojciechowska (2013) reported high level for CMIT (>5 $\mu \mathrm{g} / \mathrm{L}$ ). Also, Bürgi et al. (2009) categorized BIT and OIT as highly toxic (low EC50, LC50 or NOEC for a few aquatic organisms and low PNEC value) and concentrations in Swiss surface water were in the range of $0.1-1 \mu \mathrm{g} / \mathrm{L}$, making them compounds of interest. 
Table 6. Surface water concentrations ( $\mathrm{ng} / \mathrm{L}$ ) of some biocides used either in building materials or as PPP.

\begin{tabular}{|c|c|c|c|c|c|c|c|c|c|c|}
\hline & \multicolumn{10}{|c|}{ Concentrations in surface water (ng/L) } \\
\hline Country & France & Germany & Spain & $\begin{array}{c}\text { Switzerlan } \\
\text { d }\end{array}$ & $\begin{array}{c}\text { Other } \\
\text { Europea } \\
n \\
\text { countries }\end{array}$ & $\begin{array}{c}\text { North } \\
\text { America }\end{array}$ & Brazil & China & Australia & Tanzania \\
\hline References & $\mathrm{a}$ & $\mathrm{b}$ & $\mathrm{C}$ & d & e & $f$ & $\mathrm{~g}$ & $\mathrm{~h}$ & $\mathrm{i}$ & j \\
\hline Carbendazim & 1 & $<2.5-116$ & $\begin{array}{c}0.04- \\
11.6 \\
\end{array}$ & $2.9-206$ & $\begin{array}{c}<0.33- \\
269 \\
\end{array}$ & $21-360$ & $<8$ & $6.6-610$ & & \\
\hline IPBC & & $<5$ & & $<30$ & & & & & & \\
\hline Diuron & $20-5600$ & $2-41$ & $7.5-8550$ & $1.1-310$ & $\begin{array}{c}<0.51- \\
290\end{array}$ & $<1-910$ & $<8$ & $26-51$ & & \\
\hline Isoproturon & $10-61$ & $<1-115$ & $2.4-9.1$ & $1.1-5500$ & $1-340$ & & & & & \\
\hline Cybutryn & & $0.9-12$ & & $<4.5-6$ & 0.1 & $<7$ & 7.7-15.9 & & & \\
\hline Terbutryn & 10 & $5.3-5600$ & $0.9-30.5$ & $<4.5-50$ & $1-22$ & $<10$ & & & $1-22$ & \\
\hline Terbuthylazine & 10 & $2.3-372$ & $\begin{array}{c}0.1- \\
12600 \\
\end{array}$ & $5-40$ & $<3-254.4$ & & 102.2 & & & \\
\hline Propiconazole & 12 & $4.2-7$ & & $1.9-65$ & $<4.5-44$ & $<3-291$ & & 10 & $2-22$ & \\
\hline Tebuconazole & 14 & $2.2-12$ & $1.7-15.4$ & $1.9-86$ & $<2.7-120$ & $<3-53$ & $5.6-60.6$ & & 21 & \\
\hline Thiabiendazole & & $0.1-21$ & $0.01-1$ & & $<10-53$ & $\begin{array}{l}<3.9- \\
153.2\end{array}$ & & $<0.01$ & & 170 \\
\hline Permethrin & 14 & & & & $<0.5-97$ & $\begin{array}{c}<0.003- \\
18\end{array}$ & $\begin{array}{l}<375- \\
1650\end{array}$ & 370 & & \\
\hline Mecoprop & $5-30$ & $3-147$ & & $4-1750$ & $1.7-30$ & 5.1-94 & & & & \\
\hline
\end{tabular}

a: Blanchoud et al. (2004); Botta et al. (2012); Direction régionale et interdépartementale de l'environnement et de l'énergie d'lle-de-France (DRIEE) (2016); b: Quednow and Püttmann (2007); Van Pinxteren et al. (2009); Loos et al. (2010); Wick et al. (2010); Reemtsma et al. (2013); Wluka et al. (2016); c: Claver et al. (2006); Benvenuto et al. (2010); Gros et al. (2012); Köck-Schulmeyer et al. (2012); Campo et al. (2013); Herrero-Hernández et al. (2013); Masiá et al. (2013); Ccanccapa et al. (2016); d: Öllers et al. (2001); Singer et al. (2010); Bonvin et al. (2011); Wittmer et al. (2011a); Moschet et al. (2015); e: Bonwick et al. (1995); Benvenuto et al. (2010); Stamatis et al. (2010); Matamoros et al. (2012); Emelogu et al. (2013); Kalogridi et al. (2014); Palma et al. (2014); Vorkamp et al. (2014); Antić et al. (2015); Chitescu et al. (2015); Stipaničev et al. (2017); f: Bartelt-Hunt et al. (2009); Murray et al. (2010); Battaglin et al. (2011); Struger et al. (2011); Weston and Lydy (2012); Sengupta et al. (2013); Metcalfe et al. (2016); g: Pinheiro et al. (2011); Caldas et al. (2013); Robles-Molina et al. (2014); h: Chen et al. (2012); Heeb et al. (2012); i: Allinson et al. (2015); j: Kishimba (2004) 
Surface water concentration is expected to be at least one order of magnitude lower than of the one for urban discharges because of a dilution effect (Gros et al. 2007). However, when compared to WWTP effluents or stormwater (table 4 and figure 2), surface water concentrations are of the same order of magnitude. For example, average concentration of carbendazim ranges from 9 to $530 \mathrm{ng} / \mathrm{L}$ in WWTP effluents, from <3 to $1600 \mathrm{ng} / \mathrm{L}$ in stormwater and from 1 to $610 \mathrm{ng} / \mathrm{L}$ in surface water. Moreover, significant variability is observed. Indeed, measured concentrations depend on several parameters (Köck-Schulmeyer et al. 2012): the sampling points close to WWTP discharges generally give higher frequencies of detection and higher concentrations (Loos et al. 2010; Singer et al. 2010; Bonvin et al. 2011); the season of the year, higher quantities of biocides also used as pesticides can be observed during the pesticide application period (Quednow and Püttmann 2007; Wittmer et al. 2011a; Kalogridi et al. 2014; Antić et al. 2015); and the hydrological and weather conditions (e.g. river flow and rain intensity). For example, Palma et al. (2014) observed higher concentrations for most pesticides analyzed (including diuron, isoprotuon, terbuthylazine and mecoprop) after the first rainfalls than during the preceding wet period. Wicke et al. (2015) sampled surface water from a small river in Germany during dry and wet weathers. The reported level of biocides was mostly correlated to rainy events. The mean concentration of mecoprop was $240 \mathrm{ng} / \mathrm{L}$, while diuron and terbutryn were detected at $50 \mathrm{ng} / \mathrm{L}$. OIT was only detected twice but its concentration could reach $1.2 \mu \mathrm{g} / \mathrm{L}$. These observations highlight again the presence of multiple pathways of biocides into receiving waters: urban discharges and diffuse sources. However these studies did not identify primary sources of emissions between buildings, domestic, agriculture etc.

In order to estimate the potential risk for aquatic organisms, concentrations in receiving waters need to be compared with threshold values such as PNEC or median effective concentration (EC50) for sensitive organisms or environmental quality standards (EQS, Directive 2008/105/EC) for priority substances listed by the Water Framework Directive. EQSs are annual average concentrations that should not be exceeded in European surface water. This value is set at 200, 300, 65 and $2.5 \mathrm{ng} / \mathrm{L}$ for diuron, isoproturon, terbutryn and cybutryn, respectively. As shown in table 6, these concentrations can be exceeded across European countries. However, no annual data is available. In addition, European Directive 98/83/EC on the quality of water intended for human consumption set the maximum concentrations of each pesticide at $100 \mathrm{ng} / \mathrm{L}$ and the total concentration of pesticides at $500 \mathrm{ng} / \mathrm{L}$. Despite this Directive, the concentration levels of individual compounds or mixtures are occasionally higher in surface water. However, analyses are often run on a restricted number of compounds, making it difficult to conclude that the total concentration of pesticides is not exceeded.

As shown in Table 1, PNEC values range from $0.47 \mathrm{ng} / \mathrm{L}$ (permethrin) to $44 \mu \mathrm{g} / \mathrm{L}$ (mecoprop). Among the 20 biocides shown in table 1 , only 5 have PNEC greater than atrazine $(0.6 \mu \mathrm{g} / \mathrm{L}$ (INERIS)), which is a priority substance of the Water Framework Directive. With respect to PNEC values, most of the listed biocides (quaternary ammonium compounds, carbendazim, CMIT, diuron, isoproturon, terbuthylazine, permethrin and sometimes cybutryn and terbutryn) are expected to have an impact on aquatic organisms at lower concentrations than atrazine. However, only four of them (diuron, isoproturon, terbutryn and cybutryn) are priority substances listed in the Water Framework Directive. Moreover, although mean concentrations of the other biocides did not exceed PNEC values, it occasionally happens. It is important to note that these 
ecotoxicological values do not take into account synergistic and toxic cocktail effects although several studies have reported adverse effects of pesticide or biocide mixtures on aquatic organisms (Adam et al. 2009; Christen et al. 2014; Hua and Relyea 2014; Gandar et al. 2017; Gamet-Payrastre and Lukowicz 2017; Lukowicz et al. 2018).

EC50 values range from $1.27 \mu \mathrm{g} / \mathrm{L}$ (permethrin) to $21.2 \mathrm{mg} / \mathrm{L}$ (terbuthylazine). According to the data reported in table 6, only permethrin concentrations exceeded sometimes the EC50 values. Bioconcentration is assessed using the bioconcentration factor (BCF). As most of BCF are below 100 (except for cybuthrin, permethrin and propiconazole) it indicates that biocides tend to accumulate very little in organisms.

Concerning TPs in surface water, most studies focus either on pesticides or on mechanisms in surface water. But TPs resulting from photodegradation on the surface of buildings are not necessarily the same as those resulting from biodegradation in the river. As a result, there is little data on the TPs listed in table 3 for surface water. Singer et al. (2010) measured the desethyl terbutryn at a level of $10 \mathrm{ng} / \mathrm{L}$ both upstream and downstream a WWTP discharge in Switzerland, Moschet et al. (2014) measured this compound at concentrations lower than $5.5 \mathrm{ng} / \mathrm{L}$ in Switzerland and Wick et al. (2010) between 0.7 and $12 \mathrm{ng} / \mathrm{L}$ in German rivers. Moschet et al. (2014) measured also DCPMU, a diuron TP originating from hydrolysis or degradation in soil, at concentrations ranging from less than 10 to $22 \mathrm{ng} / \mathrm{L}$. These levels were similar to those of diuron.

A few studies reported a decreasing trend of biocide concentrations from one year to the next because of bans on some compounds or changes in agriculture practices (Botta et al. 2012; KöckSchulmeyer et al. 2012; Palma et al. 2014; Ccanccapa et al. 2016; Direction régionale et interdépartementale de l'environnement et de l'énergie d'lle-de-France (DRIEE) 2016). These examples of source reduction in agriculture are very promising steps towards protection of surface water, and such regulatory measures could also be used for the reduction at source of biocide emissions from buildings. Conversely, Palma et al. (2014) reported higher concentrations of terbuthylazine in 2011-2012 than in 2006-2007, Quednow and Püttmann (2007) did not observe any decrease of terbutryn between 2003 and 2006 despite its ban as a pesticide in 2003. This latter finding suggests the presence of some other local sources of these compounds linked to their uses as biocides.

\subsubsection{Groundwater}

In a context of increasing urbanization, infiltration systems are becoming a widespread approach for stormwater management (Tedoldi et al. 2016), which raises the question of the contamination of groundwater. Bollmann et al. (2014b) studied the occurrence of a few biocides used in building materials (terbutryn, cybutryn, carbendazim, mecoprop, isoproturon, diuron, tebuconazole, propiconazole, MIT, BIT, OIT) in infiltrating groundwater from a separated sewer system but none of them were detected. More recently, Hensen et al. (2018) investigated the transfer of three of them (OIT, diuron, terbutryn) and their TPs to groundwater via stormwater infiltration systems in an urban area. Runoff was collected in swales and percolated on underground trenches. For OIT and terbutryn, concentrations and quantification frequencies were higher in swales than in trenches because of retention or rapid degradation in soil 
(Bollmann et al. 2017a). On the contrary, diuron was more frequently quantified in trench samples than in swales, which suggests other inputs or release from soil. In groundwater, OIT and its TP-214 were infrequently detected (14\% for both) and the maximum concentration of OIT was $1.4 \mathrm{ng} / \mathrm{L}$. Diuron and its TP-219 were often quantified (100\% and 82\%, respectively) at higher concentrations after the infiltration system, up to $8.8 \mathrm{ng} / \mathrm{L}$ (i.e. an eight-fold increase) and $7.3 \mathrm{ng} / \mathrm{L}$ respectively (a mean four-fold increase). Concentrations of diuron found in groundwater were higher than those in swale and trench samples. This result again showed that diuron might be continuously released from soil. In groundwater, terbutryn and its TP-214 were mostly quantified with maximum concentrations of 7.6 and $3.3 \mathrm{ng} / \mathrm{L}$ respectively. These observations strongly suggest that diuron and terbutryn entered the groundwater via the infiltration system. For all studied compounds, concentrations in groundwater were far below the threshold value (100 ng/L for individual pesticides) set by the European Directive 98/83/EC. Further work is needed for other biocides used in building materials and their TPs, as it is clear that they can enter groundwater via infiltration systems.

\section{Conclusion and outlook}

This review highlighted that biocides used in building materials are of major concern regarding the quality of receiving waters. Widely used in buildings but also as pesticides or in households or cosmetic products, they are ubiquitous in surface water and groundwater with concentrations close to regulatory thresholds at which they can have biological effects. Many studies investigated biocidal emissions from building materials, allowing the constitution of a list of biocides used in buildings, which should be monitored in receiving waters: methylisothiazolinone, benzisothiazolinone, chloro-methylisothiazolinone, octylisothiazolinone, dichloro-octyl-isothiazolinone, diuron, isoproturon, carbendazim, iodopropynyl butylcarbamate, terbutryn, cybutryn, terbuthylazine, mecoprop, propiconazole, tebuconazole, thiabendazole, permethrin, benzalkonium, dodecyl-dimethyl ammonium and zinc pyrithione. Some studies proposed models at the scale of a city or a watershed in order to predict the biocide loads into receiving waters. Literature results indicated that biocide concentrations in stormwater, CSOs and wastewater, were in the same order of magnitude. It was proved that urban discharges in both dry and wet weather conditions could contaminate the receiving environment. In rivers, several studies reported concentrations of cybutryn, carbendazim, QAC, permethrin and phenylureas exceeding PNEC values, which imply an environmental risk for aquatic organisms.

However, many gaps in knowledge have been identified, preventing the full assessment of the environmental risks related to biocides from buildings and the proposal of new regulations. First, the present review has pointed out that (i) data is scarcer for MIT, tebuconazole, mecoprop and benzalkoniums and almost absent for zinc pyrithione in building leachates, and (ii) data is also missing for isothiazolinones, IPBC, zinc pyrithione and QAC in surface water. Additionally, transformation products are still poorly investigated although they represent crucial information to close the mass balance between the remaining stock in materials and the emitted mass loads. 
Future work should hence focus on the improvement of both analytical and experimental protocols. Limits of detection and quantification for zinc pyrithione, IPBC and isothiazolinones have to be improved in order to allow their detection and quantification at trace levels. Harmonized methods, such as EN 16105 procedure (CEN 2011), are required so that leachability can be compared between several materials. Concerning the biocide transfer into receiving waters, the comparison of concentrations is not sufficient to prioritize the major pathways. Comparing mass loads would be more relevant and helpful for risk assessment. Models can be valuable tools to assess biocide mass loads into receiving waters. However, much information is required including, consumption data or sales volumes, amount of rainfall reaching façades and turned into runoff, façade surface area, etc., which are often not available. Additionally, the representativeness of the already developed models and the quality of their inputs have to be improved by considering the variability of watersheds or cities and the complexity of sewer networks. Moreover, these approaches were based on individual chemical substances, which is insufficient for risk assessment and further research on cocktail effects or in-situ bioassays appears crucial.

The review also highlighted several potential technical solutions and policy actions to reduce biocide emissions from building materials and their transfer to receiving waters. The first solution should be the improvement of products formulations such as adding a top-coating on render without biocide or the encapsulation of biocides in polymer microspheres or silica, which slows down their release. Concerning roof treatment practices, the application of products containing biocidal substances should be restricted to specific cases where technical problems justify the requirement of roof de-mossing, and doses that are employed to treat these problems should be limited. Another solution is based on the regulation concerning both the ban of the most toxic substances and the addition of biocides in monitoring programs, which are not taken into account in the actual European survey programs. For instance, (i) OIT and DCOIT are among the most toxic substances presented in this work, but their concentrations in the aquatic environment are still unknown; (ii) QAC are rarely monitored but concentrations generally exceeded PNEC values, in particular concerning benzalkonium C12; and (iii) compounds like diuron and isoproturon, which are banned as PPP but still used as biocides, should be banned as PNEC values are often exceeded in rivers. Finally, our review underlines the necessity of a close link between researchers and industrials or policy makers (cf. the two examples for mecoprop, see paragraph 3.2.3) to reduce biocide emissions and limit their transfer into rivers, and, as a consequence, to significantly improve water quality in urban areas. 


\section{Author Contributions}

The manuscript was written through contributions of all authors. All authors have given approval to the final version of the manuscript.

\section{Notes}

The authors declare no competing financial interest

\section{ACKNOWLEDGMENT}

The authors gratefully acknowledge the Central Laboratory of the Police Prefecture (LCPP) for the funding of this work. The study has been performed within the framework of the OPUR research program funded by the Seine- Normandy Water Agency, the City of Paris, the greater Paris sanitation authority (SIAAP), the Hauts-de-Seine Departmental Council, the Seine SaintDenis Departmental Council and the Val-de-Marne Departmental Council. The authors also thank Pr. Laure Garrigue-Antar, Dr. Rachid Dris and Dr Maolida Nihemaiti for their careful reading of the article.

\section{ABBREVIATIONS}

$\mathrm{BCF}$, bioconcentration factor; BIT, 1,2-benzisothiazol-3(2H)-one; BPR, biocidal product regulation; $\mathrm{BZK}$, benzalkonium; $\mathrm{CB}$, cybutryn; $\mathrm{CBZ}$, carbendazim; CMIT, 5-chloro-2-methyl-4isothiazolin-3-one; CSO, combined sewer overflows; DCOIT, 4,5-dichloro-2-n-octyl-4-isothiazolin3-one; DDAC, dimethydidecyl ammonium chloride; DR, diuron; EC50, half maximal effective concentration; IP, isoproturon; IPBC, lodopropynyl butylcarbamate; LOD, limit of detection; LOQ, limit of quantification; MCPP, mecoprop; MIT, 2-methyl-4-isothiazolin-3-one; MW, molecular weight; ND, not detected; OIT, octhilinone; PNEC, predicted no effect concentration; PPP, plant protection product; $\mathrm{QAC}$, quaternary ammonium compounds; TB, terbutryn; TEB, tebuconazole; TP, transformation product; UV, ultraviolet; WS, water solubility; WWTP, wastewater treatment plant; ZnPT, zinc pyrithione. 


\section{REFERENCES}

Adam O, Badot P-M, Degiorgi F, Crini G (2009) Mixture toxicity assessment of wood preservative pesticides in the freshwater amphipod Gammarus pulex (L.). Ecotoxicology and Environmental Safety 72:441-449. doi: 10.1016/j.ecoenv.2008.07.017

Allinson G, Zhang P, Bui A, et al (2015) Pesticide and trace metal occurrence and aquatic benchmark exceedances in surface waters and sediments of urban wetlands and retention ponds in Melbourne, Australia. Environmental Science and Pollution Research 22:10214-10226. doi: 10.1007/s11356-015-4206-3

Andersson Trojer M, Nordstierna L, Bergek J, et al (2015) Use of microcapsules as controlled release devices for coatings. Advances in Colloid and Interface Science 222:18-43. doi: 10.1016/j.cis.2014.06.003

Antić N, Radišić M, Radović T, et al (2015) Pesticide Residues in the Danube River Basin in Serbia - a Survey during 2009-2011: Pesticide Residues in the Danube River Basin in Serbia. CLEAN - Soil, Air, Water 43:197-204. doi: 10.1002/clen.201200360

Bandow N, Gartiser S, Ilvonen O, Schoknecht U (2018) Evaluation of the impact of construction products on the environment by leaching of possibly hazardous substances. Environmental Sciences Europe 30:. doi: 10.1186/s12302-018-0144-2

Baranowska I, Wojciechowska I (2013) The determination of preservatives in cosmetics and environmental waters by HPLC. Pol J Environ Study 22:1609-94

Barco-Bonilla N, Romero-González R, Plaza-Bolaños P, et al (2013) Priority organic compounds in wastewater effluents from the Mediterranean and Atlantic basins of Andalusia (Spain). Environmental Science: Processes \& Impacts 15:2194. doi: 10.1039/c3em00329a

Bartelt-Hunt SL, Snow DD, Damon T, et al (2009) The occurrence of illicit and therapeutic pharmaceuticals in wastewater effluent and surface waters in Nebraska. Environmental Pollution 157:786-791. doi: 10.1016/j.envpol.2008.11.025

Barzman M, Bàrberi P, Birch ANE, et al (2015) Eight principles of integrated pest management. Agronomy for Sustainable Development 35:1199-1215. doi: 10.1007/s13593-015-0327-9

Başer S, Erkoç F, Selvi M, Koçak O (2003) Investigation of acute toxicity of permethrin on guppies Poecilia reticulata. Chemosphere 51:469-474. doi: 10.1016/S0045-6535(03)00033-X

Battaglin WA, Sandstrom MW, Kuivila KM, et al (2011) Occurrence of Azoxystrobin, Propiconazole, and Selected Other Fungicides in US Streams, 2005-2006. Water, Air, \& Soil Pollution 218:307-322. doi: 10.1007/s11270-010-0643-2

Benvenuto F, Marín JM, Sancho JV, et al (2010) Simultaneous determination of triazines and their main transformation products in surface and urban wastewater by ultra-high-pressure liquid chromatography-tandem mass spectrometry. Analytical and Bioanalytical Chemistry 397:27912805. doi: 10.1007/s00216-010-3712-x 
Bester K, Lamani X (2010) Determination of biocides as well as some biocide metabolites from façade run-off waters by solid phase extraction and high performance liquid chromatographic separation and tandem mass spectrometry detection. Journal of Chromatography A 1217:52045214. doi: 10.1016/j.chroma.2010.06.020

Birch H, Mikkelsen PS, Jensen JK, Lützhøft H-CH (2011) Micropollutants in stormwater runoff and combined sewer overflow in the Copenhagen area, Denmark. Water Science \& Technology 64:485. doi: $10.2166 /$ wst.2011.687

Blanchoud H, Farrugia F, Mouchel J-M (2004) Pesticide uses and transfers in urbanised catchments. Chemosphere 55:905-913. doi: 10.1016/j.chemosphere.2003.11.061

Bletsou AA, Jeon J, Hollender J, Archontaki E, Thomaidis NS (2015) Targeted and Non-Targeted Liquid Chromatography-Mass Spectrometric Workflows for Identification of Transformation Products of Emerging Pollutants in the Aquatic Environment. TrAC Trends in Analytical Chemistry66: 32-44.

Blocken B, Carmeliet J (2004) A review of wind-driven rain research in building science. Journal of Wind Engineering and Industrial Aerodynamics 92:1079-1130

Blocken B, Derome D, Carmeliet J (2009) Overview of research on rainwater runoff from building façades, 12th Canadian Conference on Building Science and Technology, Montreal, Quebec

Bollmann UE, Fernández-Calviño D, Brandt KK, et al (2017a) Biocide Runoff from Building Façades: Degradation Kinetics in Soil. Environmental Science \& Technology 51:3694-3702. doi: 10.1021/acs.est.6b05512

Bollmann UE, Minelgaite G, Schlüsener $M$, et al (2016) Leaching of Terbutryn and Its Photodegradation Products from Artificial Walls under Natural Weather Conditions. Environmental Science \& Technology 50:4289-4295. doi: 10.1021/acs.est.5b05825

Bollmann UE, Minelgaite G, Schlüsener M, et al (2017b) Photodegradation of octylisothiazolinone and semi-field emissions from façade coatings. Scientific Reports 7:41501. doi: 10.1038/srep41501

Bollmann UE, Ou Y, Mayer P, et al (2015a) Polyacrylate-water partitioning of biocidal compounds: Enhancing the understanding of biocide partitioning between render and water. Chemosphere 119:1021-1026. doi: 10.1016/j.chemosphere.2014.08.074

Bollmann UE, Tang C, Eriksson E, et al (2014a) Biocides in urban wastewater treatment plant influent at dry and wet weather: Concentrations, mass flows and possible sources. Water Research 60:64-74. doi: 10.1016/j.watres.2014.04.014

Bollmann UE, Vollertsen J, Bester K (2015b) Assessment on urban soil pollution by biocides from building materials 
Bollmann UE, Vollertsen J, Carmeliet J, Bester K (2014b) Dynamics of biocide emissions from buildings in a suburban stormwater catchment - Concentrations, mass loads and emission processes. Water Research 56:66-76. doi: 10.1016/j.watres.2014.02.033

Bones J, Thomas KV, Paull B (2006) Improved method for the determination of zinc pyrithione in environmental water samples incorporating on-line extraction and preconcentration coupled with liquid chromatography atmospheric pressure chemical ionisation mass spectrometry. Journal of Chromatography A 1132:157-164. doi: 10.1016/j.chroma.2006.07.068

Bonvin F, Rutler R, Chèvre N, et al (2011) Spatial and Temporal Presence of a Wastewater-Derived Micropollutant Plume in Lake Geneva. Environmental Science \& Technology 45:4702-4709. doi: 10.1021/es2003588

Bonwick GA, Sun C, Abdul-Latif $P$, et al (1995) Determination of permethrin and cyfluthrin in water and sediment by gas chromatography-mass spectrometry operated in the negative chemical ionization mode. Journal of Chromatography A 707:293-302

Botta F, Fauchon N, Blanchoud H, et al (2012) Phyt'Eaux Cités: Application and validation of a programme to reduce surface water contamination with urban pesticides. Chemosphere 86:166176. doi: 10.1016/j.chemosphere.2011.10.005

Bressy A (2010) Flux de micropolluants dans les eaux de ruissellement urbaines: effets de différents modes de gestion à l'amont (Micropollutant flux in urban runoff: effects of different upstream management methods). Ph.D. Dissertation. Université Paris-Est

Breuer K, Hofbauer W, Krueger N, et al (2012) Wirksamkeit und Dauerhaftigkeit von Bioziden in Bautenbeschichtungen. Bauphysik 34:170-182. doi: 10.1002/bapi.201200021

Bucheli TD, Müller SR, Voegelin A, Schwarzenbach RP (1998) Bituminous Roof Sealing Membranes as Major Sources of the Herbicide (R-S)-Mecoprop in Roof Runoff Waters: Potential Contamination of Groundwater and Surface Waters. Environmental Science \& Technology 32:3465-3471. doi: 10.1021/es980318f

Bürgi D, Knechtenhofer L, Meier I, Giger W (2009) Priorisierung von bioziden Wirkstoffen aufgrund der potenziellen Gefährdung schweizerischer Oberflächengewässer. Umweltwissenschaften und Schadstoff-Forschung 21:16-26. doi: 10.1007/s12302-008-0032-2

Burkhardt M, Junghans M, Zuleeg S, et al (2009) Biozide in Gebäudefassaden - ökotoxikologische Effekte, Auswaschung und Belastungsabschätzung für Gewässer. Umweltwissenschaften und Schadstoff-Forschung 21:36-47. doi: 10.1007/s12302-008-0033-1

Burkhardt M, Kupper T, Hean S, et al (2007) Biocides used in building materials and their leaching behavior to sewer systems. Water Science \& Technology 56:63. doi: 10.2166/wst.2007.807

Burkhardt M, Zuleeg S, Vonbank R, et al (2012) Leaching of Biocides from Façades under Natural Weather Conditions. Environ Sci Technol 46:5497-5503. doi: 10.1021/es2040009 
Burkhardt M, Zuleeg S, Vonbank R, et al (2011) Leaching of additives from construction materials to urban storm water runoff. Water Science \& Technology 63:1974. doi: 10.2166/wst.2011.128

Caldas SS, Bolzan CM, Guilherme JR, et al (2013) Determination of pharmaceuticals, personal care products, and pesticides in surface and treated waters: method development and survey. Environmental Science and Pollution Research 20:5855-5863. doi: 10.1007/s11356-013-1650-9

Campo J, Masiá A, Blasco C, Picó Y (2013) Occurrence and removal efficiency of pesticides in sewage treatment plants of four Mediterranean River Basins. Journal of Hazardous Materials 263:146-157. doi: 10.1016/j.jhazmat.2013.09.061

Ccanccapa A, Masiá A, Navarro-Ortega A, et al (2016) Pesticides in the Ebro River basin: Occurrence and risk assessment. Environmental Pollution 211:414-424. doi: 10.1016/j.envpol.2015.12.059

CEN (2011) EN 16105: Paints and Varnishes - Laboratory Method for Determination of Release of Substances from Coatings in Intermittent Contact with Water. 18

Chem Spider. www.chemspider.com. Accessed 1 Dec 2016

Chen Z-F, Ying G-G, Lai H-J, et al (2012) Determination of biocides in different environmental matrices by use of ultra-high-performance liquid chromatography-tandem mass spectrometry. Analytical and Bioanalytical Chemistry 404:3175-3188. doi: 10.1007/s00216-012-6444-2

Chitescu CL, Kaklamanos G, Nicolau Al, Stolker AAM (Linda) (2015) High sensitive multiresidue analysis of pharmaceuticals and antifungals in surface water using U-HPLC-Q-Exactive Orbitrap HRMS. Application to the Danube river basin on the Romanian territory. Science of The Total Environment 532:501-511. doi: 10.1016/j.scitotenv.2015.06.010

Christen V, Crettaz P, Fent K (2014) Additive and synergistic antiandrogenic activities of mixtures of azol fungicides and vinclozolin. Toxicology and Applied Pharmacology 279:455-466. doi: 10.1016/j.taap.2014.06.025

Clara M, Scharf S, Scheffknecht C, Gans O (2007) Occurrence of selected surfactants in untreated and treated sewage. Water Research 41:4339-4348. doi: 10.1016/j.watres.2007.06.027

Clara M, Windhofer G, Weilgony P, et al (2012) Identification of relevant micropollutants in Austrian municipal wastewater and their behaviour during wastewater treatment. Chemosphere 87:1265-1272. doi: 10.1016/j.chemosphere.2012.01.033

Claver A, Ormad P, Rodríguez L, Ovelleiro JL (2006) Study of the presence of pesticides in surface waters in the Ebro river basin (Spain). Chemosphere 64:1437-1443. doi: 10.1016/j.chemosphere.2006.02.034

Coutu S, Rota C, Rossi L, Barry DA (2012a) Modelling city-scale façade leaching of biocide by rainfall. Water Research 46:3525-3534. doi: 10.1016/j.watres.2012.03.064 
Coutu S, Del Giudice D, Rossi L, Barry DA (2012b) Modeling of façade leaching in urban catchments. Water resources research 48:

Cuppen JG, Van den Brink PJ, Camps E, et al (2000) Impact of the fungicide carbendazim in freshwater microcosms. I. Water quality, breakdown of particulate organic matter and responses of macroinvertebrates. Aquatic toxicology 48:233-250

Deborde M, Printemps-Vacquier C, Nicolas-Herman T, Lasek F (2016) Projet BIOTECH « Biocides, Occurrence, Traitement et Effluents Hospitaliers " - PHASE 1: Identification des principaux émetteurs de biocides dans le système de collecte et évaluation de la contribution du $\mathrm{CHU}$ à l'échelle de l'Agglomération - Rapport intermédiaire

Ding W-H, Liao Y-H (2001) Determination of Alkylbenzyldimethylammonium Chlorides in River Water and Sewage Effluent by Solid-Phase Extraction and Gas Chromatography/Mass Spectrometry. Analytical Chemistry 73:36-40. doi: 10.1021/ac000655i

Direction régionale et interdépartementale de l'environnement et de l'énergie d'lle-de-France (DRIEE) (2016) Info'Phyto 9 : Etat de la contamination des eaux superficielles par les pesticides en région Ile-de-France - Résultats des campagnes 2012 et 2013 et évolution historique

Dulio V, von der Ohe PC, Botta F, et al (2015) The NORMAN Network - Special view on biocides as emerging substances, Workshop presentation, 25-26 June 2015, Berlin, Germany, accessible at http://www.norman-network.net/?q=node/230

Edge M, Allen NS, Turner D, et al (2001) The enhanced performance of biocidal additives in paints and coatings. Progress in organic coatings 43:10-17

Ekblad M (2014) Stormwater treatment-Sorption of organic biocides from paints and renders, Master Thesis number: 2014-11. Lund University

Emelogu ES, Pollard P, Robinson CD, et al (2013) Investigating the significance of dissolved organic contaminants in aquatic environments: Coupling passive sampling with in vitro bioassays. Chemosphere 90:210-219. doi: 10.1016/j.chemosphere.2012.06.041

EQS (2011) Cybutryn EQS Dossier, prepared by the Sub-Group on Review of the Priority Substances List (under Working Group E of the Common Implementation Strategy for the Water Framework Directive) and reviewed by the Scientific Committee on Health and Environmental Risks (SCHER)

Erich SJF, Baukh V (2016) Modelling biocide release based on coating properties. Progress in Organic Coatings 90:171-177. doi: 10.1016/j.porgcoat.2015.10.009

European Chemical Agency. www.echa.europa.eu/fr/search-chemicals. Accessed 1 Dec 2016

European Parliament and Council (2013) Directive 2013/39/EU amending directives 2000/60/EC and $2008 / 105 / E C$ as regards priority substances in the field of water policy. Off J Eur Communities: Legis L 226:1-17 
European Parliament and Council (2012) Regulation (EU) No 528/2012 concerning the making available on the market and use of biocidal products. Off J Eur Union L 167:1-122

European Parliament and Council (1991) Directive 91/414/EEC concerning the placing of plan pretection products on the market. Off J Eur Communities: Legis L 330:32-54

European Parliament and Council (2009a) Regulation (EC) No 1223/2009 on cosmetic products. Off J Eur Union L 342:59-209

European Parliament and Council (2009b) DIRECTIVE 2009/128/EC of 21 October 2009 establishing a framework for Community action to achieve the sustainable use of pesticides. Off J Eur Communities: Legis L 309:71-86

European Parliament and Council (1998) Directive 98/8/EC concerning the placing of bocidal products on the market. Off J Eur Communities: Legis L 123:1-63

European Parliament and Council (2015a) Assessment Report CMIT/MIT (PT6 Biocide for use as preservatives for products during storage)

European Parliament and Council (2015b) Assessment Report Didecyldimethylammonium chloride (PT8 wood preservative)

European Parliament and Council (2015c) Assessment Report Alkyl (C12-16) dimethylbenzyl ammonium chloride (PT8 wood preservative)

European Parliament and Council (2014) Assessment Report Permethrin (PT8 wood preservative)

European Parliament and Council (2015d) Assessment Report Propiconazole (PT7 film preservatives)

European Parliament and Council (2008) Assessment Report Thiabendazole (PT8 wood preservatives)

Fenner K, Canonica S, Wackett LP, Elsner M (2013) Evaluating pesticide degradation in the environment: blind spots and emerging opportunities. science 341:752-758

Ferrer I, Furlong ET (2001) Identification of Alkyl Dimethylbenzylammonium Surfactants in Water Samples by Solid-Phase Extraction Followed by Ion Trap LC/MS and LC/MS/MS. Environmental Science \& Technology 35:2583-2588. doi: 10.1021/es001742v

Friedman M, Ash JF, Bry RE, Simonaitis RA (1979) Mothproofing wool and wool blends with permethrin. The American Chemical Society 27:331-336

Gamet-Payrastre L, Lukowicz C (2017) Les effets des mélanges de pesticides. Cahiers de Nutrition et de Diététique 52:234-238. doi: 10.1016/j.cnd.2017.03.002 
Gandar A, Laffaille P, Marty-Gasset N, et al (2017) Proteome response of fish under multiple stress exposure: Effects of pesticide mixtures and temperature increase. Aquatic Toxicology 184:61-77. doi: 10.1016/j.aquatox.2017.01.004

Gasperi J, Garnaud S, Rocher V, Moilleron R (2008) Priority pollutants in wastewater and combined sewer overflow. Science of The Total Environment 407:263-272. doi: 10.1016/j.scitotenv.2008.08.015

Gasperi J, Sebastian C, Ruban V, et al (2013) Micropollutants in urban stormwater: occurrence, concentrations, and atmospheric contributions for a wide range of contaminants in three French catchments. Environmental Science and Pollution Research 21:5267-5281. doi: 10.1007/s11356013-2396-0

Gaylarde CC, Morton LHG, Loh K, Shirakawa MA (2011) Biodeterioration of external architectural paint films - A review. International Biodeterioration \& Biodegradation 65:1189-1198. doi: 10.1016/j.ibiod.2011.09.005

Geissen V, Mol H, Klumpp E, et al (2015) Emerging pollutants in the environment: A challenge for water resource management. International Soil and Water Conservation Research 3:57-65. doi: 10.1016/j.iswcr.2015.03.002

Gómez MJ, Martínez Bueno MJ, Lacorte S, et al (2007) Pilot survey monitoring pharmaceuticals and related compounds in a sewage treatment plant located on the Mediterranean coast. Chemosphere 66:993-1002. doi: 10.1016/j.chemosphere.2006.07.051

Gromaire MC, Van de Voorde A, Lorgeoux C, Chebbo G (2015) Benzalkonium runoff from roofs treated with biocide products - In situ pilot-scale study. Water Research 81:279-287. doi: 10.1016/j.watres.2015.05.060

Gros M, Petrović M, Barceló D (2007) Wastewater treatment plants as a pathway for aquatic contamination by pharmaceuticals in the Ebro river basin (northeast Spain). Environmental Toxicology and Chemistry 26:1553-1562

Gros M, Rodríguez-Mozaz S, Barceló D (2012) Fast and comprehensive multi-residue analysis of a broad range of human and veterinary pharmaceuticals and some of their metabolites in surface and treated waters by ultra-high-performance liquid chromatography coupled to quadrupolelinear ion trap tandem mass spectrometry. Journal of Chromatography A 1248:104-121. doi: 10.1016/j.chroma.2012.05.084

Guillossou R, Le Roux J, Mailler R, et al (2019) Organic micropollutants in a large wastewater treatment plant: What are the benefits of an advanced treatment by activated carbon adsorption in comparison to conventional treatment? Chemosphere 218:1050-1060

Gustafson DI (1989) Groundwater ubiquity score: a simple method for assessing pesticide leachability. Environmental toxicology and chemistry 8:339-357 
Heeb F, Singer H, Pernet-Coudrier B, et al (2012) Organic Micropollutants in Rivers Downstream of the Megacity Beijing: Sources and Mass Fluxes in a Large-Scale Wastewater Irrigation System. Environmental Science \& Technology 46:8680-8688. doi: 10.1021/es301912q

Hensen B, Lange J, Jackisch N, et al (2018) Entry of biocides and their transformation products into groundwater via urban stormwater infiltration systems. Water research 144:413-423

Herrero-Hernández E, Andrades MS, Álvarez-Martín A, et al (2013) Occurrence of pesticides and some of their degradation products in waters in a Spanish wine region. Journal of Hydrology 486:234-245. doi: 10.1016/j.jhydrol.2013.01.025

Hua J, Relyea R (2014) Chemical cocktails in aquatic systems: Pesticide effects on the response and recovery of $>20$ animal taxa. Environmental Pollution 189:18-26. doi: 10.1016/j.envpol.2014.02.007

INERIS Portail Substances Chimiques. http://www.ineris.fr/substances/fr/. Accessed 1 Dec 2016

Ingham PE, McNeil SJ, Sunderland MR (2012) Functional Finishes for Wool-Eco Considerations. Advanced Materials Research 441:33-43. doi: 10.4028/www.scientific.net/AMR.441.33

INRS (2005) Chlorure d'alkyldiméthylbenzylammonium - Fiche toxicologique

Janin A, Coudert L, Riche P, et al (2011) Application of a CCA-treated wood waste decontamination process to other copper-based preservative-treated wood after disposal. Journal of Hazardous Materials 186:1880-1887. doi: 10.1016/j.jhazmat.2010.12.094

Juergensen L, Busnarda J, Caux P-Y, Kent R (2000) Fate, behavior, and aquatic toxicity of the fungicide IPBC in the Canadian environment. Environmental Toxicology 15:201-213

Jungnickel C, Stock F, Brandsch T, Ranke J (2008) Risk assessment of biocides in roof paint: Part 1: Experimental determination and modelling of biocide leaching from roof paint. Environmental Science and Pollution Research 15:258-265. doi: 10.1065/espr2007.12.465

Kaegi R, Sinnet B, Zuleeg S, et al (2010) Release of silver nanoparticles from outdoor façades. Environmental Pollution 158:2900-2905. doi: 10.1016/j.envpol.2010.06.009

Kahle M, Buerge IJ, Hauser A, et al (2008) Azole Fungicides: Occurrence and Fate in Wastewater and Surface Waters. Environmental Science \& Technology 42:7193-7200. doi: 10.1021/es8009309

Kaiser J-P, Zuin S, Wick P (2013) Is nanotechnology revolutionizing the paint and lacquer industry? A critical opinion. Science of The Total Environment 442:282-289. doi: 10.1016/j.scitotenv.2012.10.009

Kalogridi E-C, Christophoridis C, Bizani E, et al (2014) Part I: Temporal and spatial distribution of multiclass pesticide residues in lake waters of Northern Greece: application of an optimized SPEUPLC-MS/MS pretreatment and analytical method. Environmental Science and Pollution Research 21:7239-7251. doi: 10.1007/s11356-014-2793-z 
Kishimba M (2004) The status of pesticide pollution in Tanzania. Talanta 64:48-53. doi: 10.1016/j.talanta.2003.11.047

Köck-Schulmeyer M, Ginebreda A, González S, et al (2012) Analysis of the occurrence and risk assessment of polar pesticides in the Llobregat River Basin (NE Spain). Chemosphere 86:8-16. doi: 10.1016/j.chemosphere.2011.08.034

Kreuzinger N, Fuerhacker M, Scharf S, et al (2007) Methodological approach towards the environmental significance of uncharacterized substances - quaternary ammonium compounds as an example. Desalination 215:209-222. doi: 10.1016/j.desal.2006.10.036

Kukowski K, Martinská V, Krishnamoorthy G, et al (2016) Diffusion of tebuconazole into softwood under ambient conditions and its distribution in freshly treated and aged wood. International Journal of Heat and Mass Transfer 102:1257-1266. doi: 10.1016/j.ijheatmasstransfer.2016.06.097

Kupper T, Burkhardt M, Rossi L, et al (2005) Biocidal products in urban water systems-occurrence, fate and impacts. Literature review and proposal for further studies carried out within the project Urbic. Eawag

Kupper T, Plagellat C, Brändli RC, et al (2006) Fate and removal of polycyclic musks, UV filters and biocides during wastewater treatment. Water Research 40:2603-2612. doi: 10.1016/j.watres.2006.04.012

Lamichhane JR, Dachbrodt-Saaydeh S, Kudsk P, Messéan A (2016) Towards a reduced reliance on conventional pesticides in European agriculture. Plant Disease 100:10-24

Launay MA, Dittmer U, Steinmetz H (2016) Organic micropollutants discharged by combined sewer overflows - Characterisation of pollutant sources and stormwater-related processes. Water Research 104:82-92. doi: 10.1016/j.watres.2016.07.068

Lechenet M, Dessaint F, Py G, et al (2017) Reducing pesticide use while preserving crop productivity and profitability on arable farms. Nature Plants 3:17008. doi: $10.1038 /$ nplants. 2017.8

Loos R, Locoro G, Contini S (2010) Occurrence of polar organic contaminants in the dissolved water phase of the Danube River and its major tributaries using SPE-LC-MS2 analysis. Water Research 44:2325-2335. doi: 10.1016/j.watres.2009.12.035

Luft A, Wagner M, Ternes TA (2014) Transformation of Biocides Irgarol and Terbutryn in the Biological Wastewater Treatment. Environmental Science \& Technology 48:244-254. doi: 10.1021/es403531d

Lukowicz C, Ellero-Simatos S, Régnier M, et al (2018) Metabolic Effects of a Chronic Dietary Exposure to a Low-Dose Pesticide Cocktail in Mice: Sexual Dimorphism and Role of the Constitutive Androstane Receptor. Environmental Health Perspectives 126:067007. doi: 10.1289/EHP2877 
Luo Y, Spurlock F, Jiang W, et al (2013) Pesticide washoff from concrete surfaces: Literature review and a new modeling approach. Water research 47:3163-3172

Lupsea M, Tiruta-Barna L, Schiopu N, Schoknecht U (2013) Modelling inorganic and organic biocide leaching from CBA-amine (Copper-Boron-Azole) treated wood based on characterisation leaching tests. Science of The Total Environment 461-462:645-654. doi: 10.1016/j.scitotenv.2013.05.037

Mailler R, Gasperi J, Coquet Y, et al (2015) Study of a large scale powdered activated carbon pilot: Removals of a wide range of emerging and priority micropollutants from wastewater treatment plant effluents. Water Research 72:315-330. doi: 10.1016/j.watres.2014.10.047

Margot J, Kienle C, Magnet A, et al (2013) Treatment of micropollutants in municipal wastewater: Ozone or powdered activated carbon? Science of The Total Environment 461-462:480-498. doi: 10.1016/j.scitotenv.2013.05.034

Martínez-Carballo E, Sitka A, González-Barreiro C, et al (2007) Determination of selected quaternary ammonium compounds by liquid chromatography with mass spectrometry. Part I. Application to surface, waste and indirect discharge water samples in Austria. Environmental Pollution 145:489-496. doi: 10.1016/j.envpol.2006.04.033

Masiá A, Ibáñez M, Blasco C, et al (2013) Combined use of liquid chromatography triple quadrupole mass spectrometry and liquid chromatography quadrupole time-of-flight mass spectrometry in systematic screening of pesticides and other contaminants in water samples. Analytica Chimica Acta 761:117-127. doi: 10.1016/j.aca.2012.11.032

Matamoros V, Arias CA, Nguyen LX, et al (2012) Occurrence and behavior of emerging contaminants in surface water and a restored wetland. Chemosphere 88:1083-1089. doi: 10.1016/j.chemosphere.2012.04.048

Metcalfe CD, Sultana T, Li H, Helm PA (2016) Current-use pesticides in urban watersheds and receiving waters of western Lake Ontario measured using polar organic chemical integrative samplers (POCIS). Journal of Great Lakes Research 42:1432-1442. doi: 10.1016/j.jgIr.2016.08.004

Morasch B, Bonvin F, Reiser $\mathrm{H}$, et al (2010) Occurrence and fate of micropollutants in the Vidy Bay of Lake Geneva, Switzerland. Part II: Micropollutant removal between wastewater and raw drinking water. Environmental Toxicology and Chemistry 29:1649-1657. doi: 10.1002/etc.222

Moschet C, Vermeirssen ELM, Singer HP, et al (2015) Evaluation of in-situ calibration of Chemcatcher passive samplers for 322 micropollutants in agricultural and urban affected rivers. Water Research 71:306-317. doi: 10.1016/j.watres.2014.12.043

Murray KE, Thomas SM, Bodour AA (2010) Prioritizing research for trace pollutants and emerging contaminants in the freshwater environment. Environmental Pollution 158:3462-3471. doi: 10.1016/j.envpol.2010.08.009 
Nautiel, SDS Product Bio Microdor. www.nautiel.es/wp-content/uploads/2014/05/BioMicrodor-66_375-V6-FDS-EN-Nautiel.pdf

Nordstierna L, Abdalla AA, Masuda M, et al (2010) Molecular release from painted surfaces: Free and encapsulated biocides. Progress in Organic Coatings 69:45-48. doi: 10.1016/j.porgcoat.2010.05.002

Öllers S, Singer HP, Fässler P, Müller SR (2001) Simultaneous quantification of neutral and acidic pharmaceuticals and pesticides at the low-ng/l level in surface and waste water. Journal of chromatography A 911:225-234

Palma P, Köck-Schulmeyer M, Alvarenga P, et al (2014) Risk assessment of pesticides detected in surface water of the Alqueva reservoir (Guadiana basin, southern of Portugal). Science of The Total Environment 488-489:208-219. doi: 10.1016/j.scitotenv.2014.04.088

PAN Pesticides Database. http://www.pesticideinfo.org/. Accessed 1 Dec 2016

Paulus W (2005) Directory of Microbicides for the Protection of Materials: A Handbook. Springer, Dordrecht, Netherlands

Pena-Poza J (2018) Effect of biological colonization on ceramic roofing tiles by lichens and a combined laser and biocide procedure for its removal. International Biodeterioration 9

Pereyra AM, Gonzalez MR, Rosato VG, Basaldella El (2014) A-type zeolite containing Ag+/Zn2+ as inorganic antifungal for waterborne coating formulations. Progress in Organic Coatings 77:213218. doi: 10.1016/j.porgcoat.2013.09.008

Peris-Vicente J, Roca-Genovés P, Tayeb-Cherif K, Esteve-Romero J (2016) Development and validation of a method to determine thiabendazole and o-phenylphenol in wastewater using micellar liquid chromatography-fluorescence detection: Liquid Phase Separations. ELECTROPHORESIS 37:2517-2521. doi: 10.1002/elps.201500580

Pinheiro A de S, da Rocha GO, de Andrade JB (2011) A SDME/GC-MS methodology for determination of organophosphate and pyrethroid pesticides in water. Microchemical Journal 99:303-308. doi: 10.1016/j.microc.2011.05.019

PohL K, Dulio V., Botta F., Schwarzbauer J. and Rüdel H. (2015). Environmental Monitoring of Biocides in Europe: Compartment-Specific Strategies-Workshop Report (June 25-26 2015, Berlin).

Quednow K, Püttmann W (2007) Monitoring terbutryn pollution in small rivers of Hesse, Germany. Journal of Environmental Monitoring 9:1337. doi: 10.1039/b711854f

Rafoth A, Gabriel S, Sacher F, Brauch H-J (2007) Analysis of isothiazolinones in environmental waters by gas chromatography-mass spectrometry. Journal of Chromatography A 1164:74-81. doi: 10.1016/j.chroma.2007.07.040 
Reemtsma T, Alder L, Banasiak U (2013) Emerging pesticide metabolites in groundwater and surface water as determined by the application of a multimethod for 150 pesticide metabolites. Water Research 47:5535-5545. doi: 10.1016/j.watres.2013.06.031

Riechel M, Schubert R-L, Caradot N, et al (2015) Austrag und Rückhalt von Mecoprop durch Maßnahmen der Regenwasserbewirtschaftung. Stuttgart

Robles-Molina J, Gilbert-López B, García-Reyes JF, Molina-Díaz A (2014) Monitoring of selected priority and emerging contaminants in the Guadalquivir River and other related surface waters in the province of Jaén, South East Spain. Science of The Total Environment 479-480:247-257. doi: 10.1016/j.scitotenv.2014.01.121

Sánchez-Bayo F, Goka K (2005) Unexpected effects of zinc pyrithione and imidacloprid on Japanese medaka fish (Oryzias latipes). Aquatic Toxicology 74:285-293. doi: 10.1016/j.aquatox.2005.06.003

Schoknecht U, Gruycheva J, Mathies H, et al (2009) Leaching of Biocides Used in Façade Coatings under Laboratory Test Conditions. Environ Sci Technol 43:9321-9328. doi: 10.1021/es9019832

Schoknecht U, Sommerfeld T, Borho N, Bagda E (2013) Interlaboratory comparison for a laboratory leaching test procedure with façade coatings. Progress in Organic Coatings 76:351359. doi: 10.1016/j.porgcoat.2012.10.001

Schoknecht U, Wegner R, Horn W, Jann O (2003) Emission of biocides from treated materials test procedures for water and air. Environmental Science and Pollution Research 10:154-161

Sengupta A, Lyons J, Smith D, et al (2013) of emerging concern (CECs) in coastal urban rivers receiving discharge of treated. Southern California Coastal Water Research Project Annual Report 13

SenStadtUm (2013) Handlungsempfehlungen zur Vermeidung der Umweltbelastung durch die Freisetzung des Herbizids Mecoprop aus wurzelfesten Bitumenbahnen

Sheng Z-G, Li Y, Fan R-M, et al (2013) Lethal synergism between organic and inorganic wood preservatives via formation of an unusual lipophilic ternary complex. Toxicology and Applied Pharmacology 266:335-344. doi: 10.1016/j.taap.2012.11.013

Shirakawa MA, Gaylarde CC, Gaylarde PM, et al (2002) Fungal colonization and succession on newly painted buildings and the effect of biocide. FEMS Microbiology Ecology 39:165-173

Sigma Aldrich. www.sigmaaldrich.com. Accessed 1 Dec 2016

Singer HP, Jaus S, Hanke I, et al (2010) Determination of biocides and pesticides by on-line solid phase extraction coupled with mass spectrometry and their behaviour in wastewater and surface water. Environmental Pollution 158:3054-3064. doi: 10.1016/j.envpol.2010.06.013 
Speksnijder P, van Ravestijn J, de Voogt P (2010) Trace analysis of isothiazolinones in water samples by large-volume direct injection liquid chromatography tandem mass spectrometry. Journal of Chromatography A 1217:5184-5189. doi: 10.1016/j.chroma.2010.06.010

Stamatis N, Hela D, Konstantinou I (2010) Occurrence and removal of fungicides in municipal sewage treatment plant. Journal of Hazardous Materials 175:829-835. doi: 10.1016/j.jhazmat.2009.10.084

Steffen, Will, Åsa Persson, Lisa Deutsch, Jan Zalasiewicz, Mark Williams, Katherine Richardson, Carole Crumley, Paul Crutzen, Carl Folke, and Line Gordon. (2011) The Anthropocene: From Global Change to Planetary Stewardship. Ambio 40 (7): 739.

Stipaničev D, Dragun Z, Repec S, et al (2017) Broad spectrum screening of 463 organic contaminants in rivers in Macedonia. Ecotoxicology and Environmental Safety 135:48-59. doi: 10.1016/j.ecoenv.2016.09.004

Struger J, Grabuski J, Cagampan S, et al (2011) Occurrence and Distribution of Sulfonylurea and Related Herbicides in Central Canadian Surface Waters 2006-2008. Bulletin of Environmental Contamination and Toxicology 87:420-425. doi: 10.1007/s00128-011-0361-5

Styszko K, Bollmann UE, Bester K (2015) Leaching of biocides from polymer renders under wet/dry cycles - Rates and mechanisms. Chemosphere 138:609-615. doi: 10.1016/j.chemosphere.2015.07.029

Styszko K, Bollmann UE, Wangler TP, Bester K (2014) Desorption of biocides from renders modified with acrylate and silicone. Chemosphere 95:188-192. doi: 10.1016/j.chemosphere.2013.08.064

Styszko K and Kupiec K (2018). The Rate of Biocide Leaching from Porous Renders. Chemical Engineering Research and Design132: 69-76.

Tedoldi D, Chebbo G, Pierlot D, Branchu P, Kovacs Y, Gromaire M-C (2017) Spatial Distribution of Heavy Metals in the Surface Soil of Source-Control Stormwater Infiltration Devices - Inter-Site Comparison. Science of The Total Environment579: 881-92. https://doi.org/10.1016/j.scitotenv.2016.10.226.

Thomas KV (1999) Determination of the antifouling agent zinc pyrithione in water samples by copper chelate formation and high-performance liquid chromatography-atmospheric pressure chemical ionisation mass spectrometry. Journal of Chromatography A 833:105-109

Tiruta-Barna L, Schiopu N (2011) Modelling inorganic biocide emission from treated wood in water. Journal of Hazardous Materials 192:1476-1483. doi: 10.1016/j.jhazmat.2011.06.064

Uhl M, Gans O, Grillitsch B, et al (2005) Grundlagen zur Risikoabschätzung für quaternäre Ammoniumverbindungen 
Uhlig S., Colson B., Schoknecht U. (2019) A Mathematical Approach for the Analysis of Data Obtained from the Monitoring of Biocides Leached from Treated Materials Exposed to Outdoor Conditions. Chemosphere228: 271-77.

University of Hertfordshire, PPDB Pesticides Properties DataBase. http://sitem.herts.ac.uk/aeru/ppdb/en/index.htm. Accessed 1 Dec 2016

Urbanczyk MM, Bester K, Bollmann UE (2019a) Multi-layered approach to determine diffusion coefficients through polymer films: Estimating the biocide release from paints. Building and Environment 148:294-298

Urbanczyk MM, Bester K, Borho N, et al (2019b) Influence of pigments on phototransformation of biocides in paints. Journal of hazardous materials 364:125-133

USEPA (2006) Registration Eligibility Decision for Alkyl Dimethyl Benzyl Ammonium Chloride (ADBAC). 113

Van de Voorde A (2012) Incidence des pratiques d'entretien des toitures sur la qualité des eaux de ruissellement: cas des traitements par produits biocides (Impact of roof maintenance practices on runoff quality: the case of biocidal products). Ph.D. Dissertation. Université Paris-Est

Van de Voorde A, Lorgeoux C, Gromaire M-C, Chebbo G (2012) Analysis of quaternary ammonium compounds in urban stormwater samples. Environmental Pollution 164:150-157. doi: 10.1016/j.envpol.2012.01.037

Van Pinxteren M, Bauer C, Popp P (2009) High performance liquid chromatography-tandem mass spectrometry for the analysis of 10 pesticides in water: A comparison between membraneassisted solvent extraction and solid phase extraction. Journal of Chromatography A 1216:58005806. doi: 10.1016/j.chroma.2009.06.027

Vermeirssen ELM, Campiche S, Dietschweiler C, et al (2018) Ecotoxicological Assessment of Immersion Samples from Façade Render Containing Free or Encapsulated Biocides: Ecotoxicity of leachates from façade renders with biocides. Environmental Toxicology and Chemistry 37:22462256. doi: 10.1002/etc.4176

Vorkamp K, Bossi R, Bester K, et al (2014) New priority substances of the European Water Framework Directive: Biocides, pesticides and brominated flame retardants in the aquatic environment of Denmark. Science of The Total Environment 470-471:459-468. doi: 10.1016/j.scitotenv.2013.09.096

Wangler TP, Zuleeg S, Vonbank R, et al (2012) Laboratory scale studies of biocide leaching from façade coatings. Building and Environment 54:168-173. doi: 10.1016/j.buildenv.2012.02.021

Weston DP, Lydy MJ (2012) Stormwater input of pyrethroid insecticides to an urban river. Environmental Toxicology and Chemistry 31:1579-1586. doi: 10.1002/etc.1847

Wick A, Fink G, Ternes TA (2010) Comparison of electrospray ionization and atmospheric pressure chemical ionization for multi-residue analysis of biocides, UV-filters and benzothiazoles in 
aqueous matrices and activated sludge by liquid chromatography-tandem mass spectrometry. Journal of Chromatography A 1217:2088-2103. doi: 10.1016/j.chroma.2010.01.079

Wicke D, Matzinger A, Rouault P (2015) Relevanz organischer Spurenstoffe im Regenwasserabfluss Berlins. Kompetenzzentrum Wasser Berlin

Wieck S, Olsson O, Kümmerer K (2016) Possible underestimations of risks for the environment due to unregulated emissions of biocides from households to wastewater. Environment international 94:695-705

Wieck S, Olsson O, Kümmerer K (2018) Not only biocidal products: Washing and cleaning agents and personal care products can act as further sources of biocidal active substances in wastewater. Environment International 115:247-256. doi: 10.1016/j.envint.2018.03.040

Wittmer I, Scheidegger R, Bader H-P, et al (2011a) Loss rates of urban biocides can exceed those of agricultural pesticides. Science of The Total Environment 409:920-932. doi: 10.1016/j.scitotenv.2010.11.031

Wittmer I, Scheidegger R, Stamm C, et al (2011b) Modelling biocide leaching from façades. Water Research 45:3453-3460. doi: 10.1016/j.watres.2011.04.003

Wittmer IK, Bader H-P, Scheidegger R, et al (2010) Significance of urban and agricultural land use for biocide and pesticide dynamics in surface waters. Water Research 44:2850-2862. doi: 10.1016/j.watres.2010.01.030

Wluka A-K, Rüdel H, Pohl K, Schwarzbauer J (2016) Analytical method development for the determination of eight biocides in various environmental compartments and application for monitoring purposes. Environmental Science and Pollution Research 23:21894-21907. doi: $10.1007 / \mathrm{s} 11356-016-7296-7$

Yamada H (2007) Behaviour, occurence, and aquatic toxicity of new antifouling biocides and preliminary assessment of risk to aquatic ecosystems. Bull Fish Res Agen 21:31-45

Zgheib S (2009) Flux et sources des polluants prioritaires dans les eaux urbaines en lien avec l'usage du territoire (Flows and sources of priority pollutants in urban waters related to the use of the territory). Ph.D. Dissertation, Ecole Nationale des Ponts et Chaussées, 2009. 